
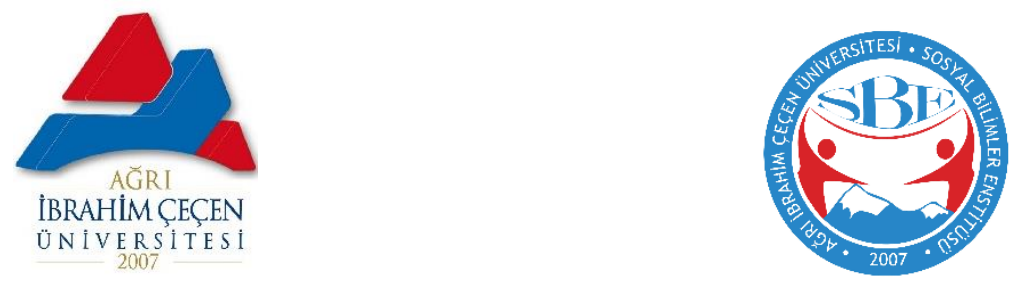

GÜNCELLENEN 5. SINIFSOSYAL BILGILER ÖĞRETIM PROGRAMININ ÖĞRETMEN GÖRÜŞLERINE GÖRE DEĞERLENDIRILMESi

Evaluation of The Updated 5th. Grade Social Studies Curriculum According to Teacher's Opinions

\title{
Vehbi SARA
}

Ağrı ibrahim Çeçen Üniversitesi, Yüksek Lisans Öğrencisi vsara_25@hotmail.com

iD https://orcid.org/0000-0003-2090-3357

\section{Emine TEYFUR}

Doç. Dr., Ağrı ibrahim Çeçen Üniversitesi, Fen Edebiyat Fakültesi eteyfur@agri.edu.tr

iD https://orcid.org/0000-0001-7869-0513

Ağrı Ibrahim Çeçen Üniversitesi Sosyal Bilimler Enstitüsü Dergisi-

Journal of Ağrı Ibrahim Çeçen University Social Sciences InstituteAiCUSBED 7/2 Ekim/October 2021 / Ağrı

ISSN: 2149-3006

ISSN: 2149-3006
\begin{tabular}{|l|l|}
\hline Makale Türü-Article Types : & \multicolumn{1}{c|}{ Araştırma Makalesi } \\
\hline Geliş Tarihi-Received Date $:$ & 27.02 .2021 \\
\hline Kabul Tarihi-Accepted Date $:$ & 30.07 .2021 \\
\hline Sayfa-Pages $: 26-57$ & https://doi.org/10.31463/aicusbed.887809 \\
\hline
\end{tabular}

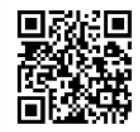

http://dergipark.gov.tr/aicusbed

This article was checked by

$\checkmark$ iThenticate 


AĞRI IBRAHIM ÇEÇEN ÜNIVERSITESi

SOSYAL BiliMLER ENSTiTÜSÜ DERGisi

Journal of Ağrı İbrahim Çeçen University Social Sciences Institute AiCUSBED 7/2, 2021, 25-57.

\section{GÜNCELLENEN 5. SINIF SOSYAL BİLGILLER ÖĞRETIM PROGRAMININ ÖĞRETMEN GÖRÜŞLERINE GÖRE DEĞERLENDİRILMESI ${ }^{I}$}

\section{Evaluation of the Updated 5th Grade Social Studies Curriculum According to the Opinions of Teachers}

Vehbi SARA

Emine TEYFUR

\section{$\ddot{O} z$}

Bu çalışmada, güncellenen 5. sınıf Sosyal Bilgiler Dersi Öğretim Programı (SBDÖP)'nı öğretmen görüşlerine göre değerlendirmek amaçlanmıştır. Çalışmanın örneklem grubunu 2017-2018 eğitim öğretim yılında Erzurum ilinin metropol ilçelerinde (Aziziye, Palandöken, Yakutiye) görev yapan 168 sosyal bilgiler öğretmeni oluşturmaktadır. Tarama modeli niteliğindeki bu araştırmada veriler USLU(2007) tarafından geliştirilen “ Öğretmenlerin Sosyal Bilgiler Programına İlişkin Görüşleri', başlıklı veri toplama aracıyla toplanmıştır. Araştırmada verilerin analizi SPSS 22.00 istatistik paket programı kıllanılmıştır. Araştırma kapsamına alınan öğretmenlerin mesleki kıdemlerine göre ankete verilen yanıtlar arasındaki farklar Kruskal Wallis $\mathrm{H}$ testi ile incelenmiştir. Öğretmenlerin ankete verdikleri yanıtlara göre; 5. sınıf SBDÖP'nin genel amaçları, vizyonu, içeriği, öğrenme ve öğretme süreçleri, ölçme ve değerlendirme ile uygulama boyutları öğretmenlerin genel olarak beklentilerini karşıladığı görülmektedir. Fakat öğretmenler, SBDÖP'de kullanılan yaklaşımlar öğrencinin empati kurma yeteneğinin gelişmesine katkıda bulunmadığını, program içeriğinin somuttan soyuta olacak şekilde düzenlenmediğini ve öğrenme alanlarının işlenişi sırasında öğretmenlerin kullanacağı yeterli uygulama örnekleri bulunmadığını kısmen düşünmektedirler. Sosyal bilgiler öğretmenleri arasında mesleki kıdem değişkenine göre anlamlı fark görülmemiştir.

Anahtar Kelimeler: Sosyal Bilgiler, Program Değerlendirme, Program Geliştirme, Öğretmen Görüşleri, Öğretim Programı, Sosyal Bilgiler Dersi Öğretim Programı

\section{Abstract}

In this study, it was aimed to evaluate the 5th Grade Social Studies Curriculum updated according to the teachers' opinions. The sample group of the study consists of 168 social studies teachers working in the metropolitan districts of Erzurum (Aziziye, Palandöken, Yakutiye) in the 2017-2018 academic year. In this

${ }^{1}$ Bu makale Vehbi Şara'nın Güncellenen 5. Sınıf Sosyal Bilgiler Öğretim Programının Öğretmen Görüşlerine Göre Değerlendirilmesi başlıklı yüksek lisans tezinden üretilmiştir.

http://dergipark.gov.tr/aicusbed 7/2 Ekim/October 2021 
research, which is survey model, the data were collected with the data collection tool titled "Teachers' Opinions on Social Studies Program" developed by Uslu (2007). Data analysis in the research SPSS 22.00 statistical package program was used. The differences between the answers given to the questionnaire according to the professional seniority of the teachers included in the research were examined with the Kruskal Wallis $\mathrm{H}$ test. According to the answers given by the teachers to the questionnaire; It is seen that the general purposes, vision, content, learning and teaching processes, measurement and evaluation and application dimensions of 5th grade SSC meet the expectations of teachers in general. However, teachers partly think that the approaches used in SSC do not contribute to the development of the student's ability to empathize, that the content of the program is not organized from concrete to abstract, and that there are not enough examples of practices that teachers can use during the processing of learning areas. There was no significant difference between social studies teachers in terms of professional seniority variable.

Keywords: Social Studies, Program Evaluation, Curriculum Development, Teachers' Views, Curriculum, Social Studies Curriculum.

\section{Giriş}

Bilgi çağı adı verilen günümüz dünyasında özellikle bilimsel ve teknolojik alanda hızlı bir değişim ve gelişim yaşanmaktadır. Ülke olarak dünyada meydana gelen bilimsel ve teknolojik alandaki değişim ve gelişmelere ayak uydurmamız gerekir. Bu değişim ve gelişimlere ayak uydurabilmeleri için de yeni nesillerden yaratıcı düşünmeleri, empati kurabilmeleri, araştırma ve sorgulama becerisine sahip olmaları, girişimci ve yaratıcı olmaları, bilgiye ulaşabilmeleri, bilgiyi kendi bilgileri ile yapılandırmaları, problemlerini çözebilmeleri ve kendi kendine karar verebilen bireyler olmaları istenmektedir. Şüphesiz bireylerin bu becerileri kazanılabilmesi eğitim sisteminde köklü değişikliler yapılmasına yani eğitimin kalitesinin artırılmasına bağlıdır. Eğitim kalitesinin içerik boyutunda öğretim programlarının taşıdığı önem büyüktür. Bu durum, geleceğin nesilleri olan çocuklarımızın daha donanımlı yetişmesi için öğretim programlarının güncellenmesine ihtiyaç duyulmaktadır. Bu nedenle özellikle kişisel, sosyal, kültürel ve bilimsel alanlarda meydana gelen gelişmeler öğretim programlarının güncellenmesine sebep olmuştur. Güncelleme çalışmalarının başlamasına uluslararası ölçekte gerçekleştirilen sınavların sonuçları, 64. ve 65. Hükümetlerin eylem planları, kalkınma planları, ulusal ve uluslararası kurum ve kuruluşların hazırladığı raporlar ile yapılan bilimsel araştırmalar etki etmiştir (TTKB, 2017).

Bilimsel ve teknolojik alandaki gelişmeler kişinin daha önce karşılaştığ sorunlara göre iletişim ve dijital kullanım sorunlarıyla karşılaşmasına neden olmaktadır. Bu sorunların çözümü için birden fazla 
disiplinin ortaya koyduğu bulgulardan faydalanılması gerekmektedir. Sosyal bilgiler dersi, öğrencilere insanlarla iyi ilişkiler kurmayı ve vatandaşta olması gereken yeterlikleri kazandırmayı amaçlar. Bu nedenle sosyal bilgiler dersi disiplinler arası yaklaşımdan yola çıkarak tarih, coğrafya, psikoloji, felsefe, sosyoloji, siyaset bilimi, hukuk, antropoloji, arkeoloji ve ekonomi gibi sosyal bilimlerin bir araya gelmesi ile oluşturulmuştur. Sosyal bilgiler dersi, öğrencilerin birçok konuda bilgi ve beceri kazanmalarına ve gündelik yaşamlarında doğru kararlar almalarına yarar sağlar. $\mathrm{Bu}$ anlatımlara bakıldığında sosyal bilgiler şu şekilde tanımlanabilir: "Etkin ve üretken bireyler yetiştirmek, öğrencilerin insani ilişkilerini ve vatandaşl1k yeterliklerini geliştirmek amacıyla sosyal bilimleri kaynaştıran bir ilköğretim dersidir.” Bu tanım 1şığında SBDÖP'nin geliştirilmesi sürecinde; toplumun ihtiyaçları, öğrencilerin yaşantıları ve sosyal bilim disiplinleri gibi üç temel kaynak esas alınmıştır. Toplumun ihtiyaçları açısından düşünüldügünde öğrencilerin sadece şimdiki ihtiyaçları değil, yetişkin olduklarında yaşamlarını devam ettirebilmeleri için ortaya çıkacak ihtiyaçları da dikkate alınmak istenmiştir (MEB, 2015).

Sosyal bilgiler dersi, sürekli olarak değişen, gündelik hayattaki problemleri tanımlayan ve bu problemlere yönelik çözüm önerileri geliştiren bireyler yetiştirmeyi amaçlar (Öztürk, 2009). Bu nedenle geçen zaman içinde ögretim programı uygulamaları ile bu uygulamalara yönelik yapılan araştırmalar SBDÖP'de güncelleme ihtiyacını ortaya çıkarmıştır. Bu ihtiyaç çerçevesinde; ilk defa sosyal bilgiler dersi 1968 Programı'na konulmuştur. Fakat 1985 yılında ise ortaokullarda okutulan sosyal bilgiler dersi kaldırılarak yerine vatandaşlık bilgisi, milli coğrafya, milli tarih dersleri konulmuştur (Kan,2010: 663).

Mili Eğitim Bakanlığı (MEB), 2005 ve 2017 yıllarına gelindiğinde önceki programlara göre köklü değişikliklere imza atmıştır. Bu değişikliklerden biri de iki programın da yapılandırmacı yaklaşımı esas almasıdır. Öğrenci merkezli olan bu yaklaşımda programın amaçları içinde yer alan temel bilgi ve becerilere öğrencilerin ulaşmasında öğretmenler rehberlik görevi üstlenmektedir (TTKB, 2017).

Ülkemizde 2016-2017 eğitim öğretim yılında başlayan müfredat güncelleme sürecinde şûra kararları, hükûmet programları ve partilerin seçim beyannameleri başta olmak üzere, farklı kurum ve kişilerce üretilmiş 350 doküman ve rapor incelenmiş. 72 program geliştirme toplantısı, 18 tanıtım ve tartışma toplantısı, 15 formatör eğitimi toplantısı, 15 öğretmen eğitimi çalışma

http://dergipark.gov.tr/aicusbed 7/2 Ekim /October 2021 
toplantısı yapılmıştır. Toplamda 120 toplantı yapılnış değişik zamanlarda ve farklı mekânlarda yapılan bu toplantılara 7.742 öğretmen ve akademisyen katılmıştır. Oluşturulan Program Geliştirme İzleme Kurulunda; Temel Eğitim, Ortaöğretim, Din Öğretimi, Meslekî ve Teknik Eğitim, Hayat Boyu Öğrenme, Özel Eğitim ve Rehberlik Hizmetleri, Ölçme Değerlendirme ve Sınav Hizmetleri Genel Müdürleri sürekli olarak yer almıştır (TTKB, 2017: 6).

Taslak müfredatlar, mufredat.meb.gov.tr adresinde 13 Ocak - 10 Şubat 2017 tarihleri arasında incelemeye ve görüş bildirimine açı tutulmuştur. Bu süre zarfinda bu adres üzerinden 175.342; TTKB kurumsal eposta adresi aracılığı ile de 8.850 görüş bildirilmiştir. Ayrıca kurumun Facebook hesabında 91.487 görüntüleme, 31.268 etkileşim; Twitter hesabında ise 530 milyon görüntüleme, 19 milyon 100 bin profil ziyareti gerçekleştirilmiştir. Kamuoyundan gelen bu geri bildirimler, akademisyen ve öğretmenlerden oluşan 360 kişinin katıldığı bir çalıştayda değerlendirilmiştir. TTKB bünyesindeki komisyonlar çalıştaydaki değerlendirmeleri büyük bir titizlikle incelemiş ve düzenlemeler yaparak taslak müfredatları TTKB'ye sunmuştur. TTKB tarafından onaylanan taslak müfredatların makam onayları, 02 Mayıs 2017 tarihinde MEB'den alınmıştır. Müfredatlar, 18 Temmuz 2017 tarihinde basın toplantısıyla kamuoyuyla paylaşılmıştır (TTKB, 2017: 6).

2017-2018 eğitim öğretim yılında 1, 5 ve 9. sinıflarda, 2018-2019 eğitim öğretim yılında ise tüm sınıflarda yenilenen müfredatların uygulanmasına başlanılmıştır.

SBDÖP'nin uygulayıcıları olan öğretmenler programı ne kadar etkili ve verimli bir şekilde uygularlarsa programın hedeflediği sonuçlara ulaşmada o kadar başarı elde edilir. Öğretmenlerin güncellenen SBDÖP'yi tanımaları, programın özelliklerini bilmeleri ve programı özümsemeleri programı uygulama ve programın eksikliklerini tespit etmede o kadar faydalı olacaktır. 2017-2018 eğitim-öğretim yılından itibaren uygulanmaya başlanan 5. sinıf SBDÖP'ye ilişkin öğretmen görüşlerini tespit etmek bu bakımından önemlidir. Araştırmanın sonuçları programın değerlendirilmesini sağlayacaktır. SBDÖP'nin mevcut durumunun incelenmesi ve programın olumlu ve olumsuz yönlerinin tespit edilmesi aynı zamanda değiştirilmesi ve geliştirilmesi gereken yönlerinin belirlenmesini sağlayacaktır.

Alanyazın incelendiğinde 2017-2018 eğitim-öğretim y1lında uygulanmaya başlayan 5. sınıf SBDÖP hakkında öğretmen görüşlerini içeren çalışmaların yeterli düzeyde olmadığı görülür. Araştırma bu yönüyle 
alanyazına önemli katkı sağlayacağı beklenmektedir. Ayrıca bu çalışmanın sonuçlarının Milli Eğitim Bakanlığı tarafindan yapılacak olan program geliştirme çalışmalarına katk1 sağlayacağı düşünülmektedir. Öğretim programının çok yeni olması nedeniyle daha çok çalışmalar, 2005 öğretim programının uygulandığı yıllarda yoğunlaşmaktadır (Çalışkan, 2014; Coşkun, 2007; Ece, 2007; Kalayc1,2007; Kılıçoğlu, 2007; Kösterelioğlu \& Özen, 2014; Memişoğlu, 2012; Sağlam, 2014; Semenderoğlu \& Gülersoy, 2005; Uslu, 2007; Yazar, 2008 ).

Güncellenen 5. sınıf SBDÖP hakkında yapılan bazı çalışmalarda programın bir ya da birkaç yönüyle analiz edilmiştir. Çalışkan (2019) tarafindan hazırlanan çalışma, SBÖP'de yer alan 5. sınıf sosyal bilgiler dersi kazanımların gerçekleştirilme düzeyi ile ilgilidir. Bu çalışmada öğretmenlerin sosyal bilgiler öğretim programında yedi öğrenme alanı içerisinde bulunan otuz dört kazanımın her birini yüksek veya çok yüksek düzeyde gerçekleştirdikleri vurgulanmıştır.

Akmeşe (2019) tarafından hazırlanan çalışma, sosyal bilgiler öğretmenlerinin 2017 ortaokul 5. sınıf sosyal bilgiler dersi öğretim programına yönelik düşüncelerini ortaya koymaya yöneliktir. Bu çalışmada, özellikle yeni öğretim programında kazanımların sayısının azaltılmasının yerinde olduğu, programın kazanım ve içerik öğesindeki değişikliklerin genel olarak ders sürecine olumlu yansıdığı vurgulanmıştır. Diğer bir çalışma ise Fırat (2019) tarafından hazırlanmıştır. Bu çalışmada 2018 y1lı itibari ile uygulamaya başlanan 5. sınıf SBDÖP'ye ilişkin öğretmen görüşleri incelenmiştir. Sosyal Bilgiler öğretmenlerinin yenilenen 5. sınıf SBDÖP'ye genel olarak orta düzeyde bir olumlu baktığı sonucuna ulaşılmıştır.

$\mathrm{Bu}$ çalışmanın esas amacı, yapılandırmacı yaklaşıma göre hazırlanan ve 2017- 2018 eğitim-öğretim yılında ilk defa uygulanan 5. sınıf SBDÖP'nin öğretmen görüşlerine göre değerlendirmektir. Bu amaçla araştırma sürecinde aşağıdaki nicel boyutlara ilişkin alt sorulara cevap aranmıştır.

\section{Problem Durumu:}

Güncellenen 5. sınıf SBDÖP'nin; genel amaçları ve temel yaklaşımı,vizyonu, içerik, öğrenme öğretme süreci, ölçme ve değerlendirme, uygulama boyutlarına ilişkin sosyal bilgiler öğretmenlerinin görüşleri nelerdir? 


\section{Alt Problemler:}

1. Sosyal bilgiler öğretmenlerinin; meslekteki kıdem değişkenine göre güncellenen 5. sınıf SBDÖP'nin; genel amaçları ve temel yaklaşımı, vizyonu boyutlarına yönelik görüşleri farklılaşmakta mıdır?

2. Güncellenen 5. sınıf SBDÖP'nin; genel amaçları ve temel yaklaşımı boyutuna ilişkin sosyal bilgiler öğretmenlerinin görüşleri nelerdir?

3. Güncellenen 5. sınıf SBDÖP'nin; içerik boyutuna ilişkin sosyal bilgiler öğretmenlerinin görüşleri nelerdir?

4. Güncellenen 5. sınıf SBDÖP'nin; öğrenme öğretme süreci boyutuna ilişkin sosyal bilgiler öğretmenlerinin görüşleri nelerdir?

5. Güncellenen 5. sınıf SBDÖP'nın; ölçme ve değerlendirme boyutuna ilişkin sosyal bilgiler öğretmenlerinin görüşleri nelerdir?

6. Güncellenen 5. sınıf SBDÖP'nin; uygulama boyutuna ilişkin sosyal bilgiler öğretmenlerinin görüşleri nelerdir?

\section{Yöntem}

Güncellenen 5. sınıf SBDÖP'nin öğretmen görüşlerine göre değerlendirmeyi amaçlayan bu araştırma, tarama modeli niteliğindedir. Tarama modelinde var olan bir duruum kendi koşulları içerisinde ve olduğu gibi yansıtmak esas alınmıştır. (Karasar, 2005). Bu bağlamda ortaokul 5. sınıf sosyal bilgiler dersine giren sosyal bilgiler öğretmenlerinin görüş ve önerileri mevcut durum doğrultusunda betimlemeye çalış1 1 mıştır.

\section{Çalışma Grubu}

Araştırmanın araştırma örneklemini Erzurum ilinin metropol ilçelerinde (Aziziye, Palandöken, Yakutiye) görev yapan iki yüz (200) sosyal bilgiler öğretmeni oluşturmaktır. Bütün öğretmenlere ulaşılmış fakat çalışma gönüllülük esasıyla yapıldığı için yüz altmış sekiz (168) öğretmenden geri dönüş alınmıştır. Buna göre çalışma verileri için geri dönüş oranı， \% 84'tür.

\section{Veri Toplama Aracı}

Bu araştırmada USLU(2007) tarafindan geliştirilen ' Öğretmenlerin Sosyal Bilgiler Programına İlişkin Görüşleri’ başlıklı veri toplama aracı kullanılmıştır. Araştırmada kullanılan veri toplama araçlarıyla toplanan veriler ile araştırmanın amacı doğrultusunda betimsel ve ilişkisel istatistikî işlemler gerçekleştirilmiştir. Ayrıca öğretmenlerin mesleki kıdem değişkenine göre, 5. sınıf SBDÖP'nin genel amaçları ve temel yaklaşımı, vizyonu boyutlarına yönelik görüşlerinin değişip değişmediği de ilişkisel olarak araştııılmıştır. Verileri elde etmek için kullanılan anket formu iki kısımdan 
oluşmaktadır. İlk kısımda ankete katılan öğretmenlere ait bilgileri içeren kişisel bilgi formu bulunmaktadır. İkinci kısımda ise öğretmenlerin güncellenen 5. sınıf SBDÖP'ye yönelik düşüncelerinin değerlendirildiği beş dereceli Likert ölçeği yer almaktadır.

\section{Verilerin Analizi}

Anket vasitasiyla toplanan verilerin analizi SPSS 22.00 istatistik paket programı ile yapılmıştır. Öğretmenlerin anketlere verdiği cevapların frekansları ve yüzde dağılımları bulunmuştur. "Programın Genel Amaçları ve Temel Yaklaşımı", "Programın Vizyonu", "Programın İçeriği”, "Öğrenme Öğretme Süreci”, “Ölçme ve Değerlendirme” ve "Uygulama Boyutu” iç yap1 tutarlılığının bulunması için Cronbach Alfa katsayısı hesaplanmıştır. Anket verilerinin faktör analizine uygun olup olmadığını değerlendirmek için Barlett testi ve Kaiser-Meyer-Olkin(KMO) testleri uygulanmıştır. Bu bulgulara dayanarak 52 maddeden oluşan anketin Açıklayıcı Faktör Analizi(exploratory factor analaysis) olarak Temel Bileşenler Yöntemi(Principal Compenent) ve Direct Oblimin Dönüştürmesi uygulanmıştır. Anketin "Programın Genel Amaçları ve Temel Yaklaşımı", "Programın Vizyonu", "Programın İçeriği", "Öğrenme Öğretme Süreci”, "Ölçme ve Değerlendirme" ve "Uygulama Boyutu" gibi alt ölçeklerine ait Korelasyon Analizi yapılmıştır. Meslekteki kıdem değişkeni için Kruskal Wallis H testi uygulanmıştır.

\section{Bulgular}

Araştırmanın alt problemi, "Sosyal bilgiler öğretmenlerinin; “'Meslekteki Kıdem,' değişkenine göre 5. sınıf SBDÖP'nin Genel Amaçları Ve Temel Yaklaşımı, Vizyonu boyutularına yönelik görüşleri farklılaşmakta mıdır?" şeklindedir.

\section{Mesleki Kıdem Değişkenine Göre Yanıtların Karşılaştırılması}

Araştırma kapsamına alınan öğretmenlerin mesleki kıdemlerine göre ankete verilen yanıtlar arasındaki farklar Kruskal Wallis $\mathrm{H}$ testi ile incelenmiş ve elde edilen bulgular Tablo-1'da verilmiştir.

Tablo 1. Öğretmenlerin Mesleki Kidemlerine Göre Ankete Verilen Yanttlar Arasındaki Farklar

\begin{tabular}{llllll}
\hline & & $\bar{X}$ & & & $\mathrm{p}$ \\
\hline $1-5 \mathrm{y} 1 \mathrm{l}$ & 26 & 44,92 & 5,30 & & \\
$6-10 \mathrm{y} 1 \mathrm{l}$ & 44 & 42,43 & 6,78 & 6,204 &, 184
\end{tabular}

http://dergipark.gov.tr/aicusbed 7/2 Ekim /October 2021 
Güncellenen 5. Sınıf Sosyal Bilgiler Öğretim Programının Öğretmen Görüşlerine Göre

Değerlendirilmesi | 33

\begin{tabular}{|c|c|c|c|c|c|c|}
\hline \multirow{3}{*}{$\begin{array}{l}\text { Programın } \\
\text { Amaçları ve Temel } \\
\text { Yaklaşımı }\end{array}$} & $11-15$ y1l & 40 & 44,03 & 7,47 & & \\
\hline & $16-20 \mathrm{y} 1 \mathrm{l}$ & 27 & 44,19 & 5,82 & & \\
\hline & 21 yıl ve üzeri & 31 & 41,52 & 7,15 & & \\
\hline \multirow[t]{5}{*}{ Programın Vizyonu } & $1-5$ yil & 26 & 11,31 & 1,96 & \multirow{5}{*}{8,390} & \multirow{5}{*}{,078 } \\
\hline & $6-10$ y1l & 44 & 10,32 & 2,23 & & \\
\hline & $11-15$ y1l & 40 & 11,08 & 1,98 & & \\
\hline & $16-20$ y1l & 27 & 10,30 & 1,59 & & \\
\hline & 21 yıl ve üzeri & 31 & 10,26 & 1,86 & & \\
\hline
\end{tabular}

Tablo-1 incelendiğinde; öğretmenlerin mesleki k1demlerine göre anketin "Programın Genel Amaçları ve Temel Yaklaşımı", "Programın Vizyonu"na ilişkin tüm KW değerleri $\mathrm{p}>0.05$ önem düzeyinde anlamsız bulunmuştur. $\mathrm{Bu}$ bulgu öğretmenlerin mesleki k1demlerine göre anketin "Programın Genel Amaçları ve Temel Yaklaşımı", "Programın Vizyonu" na verdikleri yanıtlar arasında fark olmadığını göstermektedir.

\section{Bulgular}

Programın Genel Amaçları ve Temel Yaklaşımına Yönelik

Araştırmaya katılan öğretmenlerin anketin "Programın Genel Amaçları Ve Temel Yaklaşımı" boyutuna verdikleri yanıtların genel dağılımı ile ilgili bulgular Tablo-2'de verilmiştir.

Tablo 2. Araştırmaya Katılan Öğretmenlerin Anketin "Programın Genel Amaçları Ve Temel Yaklaşımı” Boyutuna Verdikleri Yanıtların Genel Dağılımı ile İlgili Bulgular

\begin{tabular}{|c|c|c|c|c|c|}
\hline \multirow[t]{2}{*}{ Anket Maddeleri } & & f & $\%$ & $\bar{X}$ & Anlamı \\
\hline & \multicolumn{5}{|c|}{ Programın Genel Amaçları Ve Temel Yaklaşımı } \\
\hline \multirow{7}{*}{$\begin{array}{l}\text { 1. Sosyal Bilgiler } \\
\text { Dersi Öğretim } \\
\text { Programı'nın } \\
\text { genel amaçları } \\
\text { açık bir şekilde } \\
\text { ifade } \\
\text { edilmemiştir. }\end{array}$} & Hiç Katılmıyorum & 36 & 21,4 & \multirow{5}{*}{2,41} & \multirow{5}{*}{ Katılmıyorum } \\
\hline & Katılmiyorum & 63 & 37,5 & & \\
\hline & $\begin{array}{l}\text { Kismen } \\
\text { Katıliyorum }\end{array}$ & 37 & 22,0 & & \\
\hline & Katıliyorum & 28 & 16,7 & & \\
\hline & $\begin{array}{l}\text { Tamamen } \\
\text { Katıliyorum }\end{array}$ & 4 & 2,4 & & \\
\hline & Hiç Katılmıyorum & 3 & 1,8 & & \\
\hline & Katılmıyorum & 9 & 5,4 & & \\
\hline
\end{tabular}

http://dergipark.gov.tr/aicusbed 7/2 Ekim / October 2021 


\begin{tabular}{|c|c|c|c|c|c|}
\hline \multirow{3}{*}{$\begin{array}{l}\text { 2. SBDÖP'nin } \\
\text { genel amaçları } \\
\text { milli eğitimin } \\
\text { temel amaçları ile } \\
\text { uyuşmaktadır. }\end{array}$} & $\begin{array}{l}\text { Kismen } \\
\text { Katiliyorum }\end{array}$ & 20 & 11,9 & \multirow[t]{3}{*}{3,92} & \multirow[t]{3}{*}{ Katıliyorum } \\
\hline & Katıliyorum & $\begin{array}{c}10 \\
3\end{array}$ & 61,3 & & \\
\hline & $\begin{array}{l}\text { Tamamen } \\
\text { Katiliyorum }\end{array}$ & 33 & 19,6 & & \\
\hline \multirow{5}{*}{$\begin{array}{l}\text { 3. SBDÖP'de } \\
\text { benimsenen } \\
\text { yaklaşım bireyin } \\
\text { toplumsal } \\
\text { varoluşunu } \\
\text { gerçekleştirmeye } \\
\text { yöneliktir. }\end{array}$} & Hiç Katılmıyorum & 3 & 1,8 & \multirow{5}{*}{3,80} & \multirow{5}{*}{ Katıliyorum } \\
\hline & Katılmiyorum & 7 & 4,2 & & \\
\hline & $\begin{array}{l}\text { Kismen } \\
\text { Katiliyorum }\end{array}$ & 37 & 22,0 & & \\
\hline & Katıliyorum & 95 & 56,5 & & \\
\hline & $\begin{array}{l}\text { Tamamen } \\
\text { Katıliyorum }\end{array}$ & 26 & 15,5 & & \\
\hline \multirow{5}{*}{$\begin{array}{l}\text { 4. Sosyal bilgiler } \\
\text { ders kitabında yer } \\
\text { alan kavramlar } \\
\text { rahatça } \\
\text { anlaşılabilir } \\
\text { şekilde açı-seçik } \\
\text { ifade edilmiştir. }\end{array}$} & Hiç Katılmıyorum & 4 & 2,4 & \multirow{5}{*}{3,47} & \multirow{5}{*}{ Katılıyorum } \\
\hline & Katılmiyorum & 17 & 10,1 & & \\
\hline & $\begin{array}{l}\text { Kismen } \\
\text { Katıliyorum }\end{array}$ & 62 & 36,9 & & \\
\hline & Katıliyorum & 66 & 39,3 & & \\
\hline & $\begin{array}{l}\text { Tamamen } \\
\text { Katıliyorum }\end{array}$ & 19 & 11,3 & & \\
\hline \multirow{5}{*}{$\begin{array}{l}\text { 5. SBDÖP'de } \\
\text { kullanılan } \\
\text { yaklaşımlar } \\
\text { öğrencinin empati } \\
\text { kurma } \\
\text { yeteneğinin } \\
\text { gelişmesine } \\
\text { katkıda } \\
\text { bulunmamaktadır. }\end{array}$} & Hiç Katılmıyorum & 20 & 11,9 & \multirow{5}{*}{2,74} & \multirow{5}{*}{$\begin{array}{l}\text { Kismen } \\
\text { Katıliyorum }\end{array}$} \\
\hline & Katılmiyorum & 58 & 34,5 & & \\
\hline & $\begin{array}{l}\text { Kismen } \\
\text { Katıliyorum }\end{array}$ & 43 & 25,6 & & \\
\hline & Katıliyorum & 39 & 23,2 & & \\
\hline & $\begin{array}{l}\text { Tamamen } \\
\text { Katıliyorum }\end{array}$ & 8 & 4,8 & & \\
\hline \multirow{5}{*}{$\begin{array}{l}\text { 6. SBDÖP'de } \\
\text { kazanımlar } \\
\text { öğrencilerin sınıf } \\
\text { düzeyine uygun } \\
\text { değildir. }\end{array}$} & Hiç Katılmıyorum & 29 & 17,3 & \multirow{5}{*}{2,44} & \multirow{5}{*}{ Katıliyorum } \\
\hline & Katılmıyorum & 72 & 42,9 & & \\
\hline & $\begin{array}{l}\text { Kismen } \\
\text { Katıliyorum }\end{array}$ & 39 & 23,2 & & \\
\hline & Katıliyorum & 20 & 11,9 & & \\
\hline & $\begin{array}{l}\text { Tamamen } \\
\text { Katıliyorum }\end{array}$ & 8 & 4,8 & & \\
\hline \multirow{4}{*}{$\begin{array}{l}\text { 7. SBDÖP'de } \\
\text { kazanımlar } \\
\text { öğrencilerin } \\
\text { ihtiyaçlarına }\end{array}$} & Hiç Katılmıyorum & 2 & 1,2 & \multirow{4}{*}{3,64} & \multirow{4}{*}{ Katıliyorum } \\
\hline & Katılmiyorum & 12 & 7,1 & & \\
\hline & $\begin{array}{l}\text { Kismen } \\
\text { Katiliyorum }\end{array}$ & 51 & 30,4 & & \\
\hline & Katıliyorum & 82 & 48,8 & & \\
\hline
\end{tabular}

http://dergipark.gov.tr/aicusbed 7/2 Ekim /October 2021 
Güncellenen 5. Sınıf Sosyal Bilgiler Öğretim Programının Öğretmen Görüşlerine Göre

Değerlendirilmesi $\mid 35$

\begin{tabular}{|c|c|c|c|c|c|}
\hline $\begin{array}{l}\text { uygun } \\
\text { tasarlanmıştır. }\end{array}$ & $\begin{array}{l}\text { Tamamen } \\
\text { Katıliyorum }\end{array}$ & 21 & 12,5 & & \\
\hline \multirow{5}{*}{$\begin{array}{l}\text { 8. SBDÖP'de } \\
\text { kazanımlar } \\
\text { birbirini } \\
\text { desteklemektedir. }\end{array}$} & Hiç Katılmıyorum & 3 & 1,8 & \multirow{5}{*}{3,81} & \multirow{5}{*}{ Kat1liyorum } \\
\hline & Katılmiyorum & 8 & 4,8 & & \\
\hline & $\begin{array}{l}\text { Kismen } \\
\text { Katiliyorum }\end{array}$ & 36 & 21,4 & & \\
\hline & Katıliyorum & 92 & 54,8 & & \\
\hline & $\begin{array}{l}\text { Tamamen } \\
\text { Katıliyorum }\end{array}$ & 29 & 17,3 & & \\
\hline \multirow{5}{*}{$\begin{array}{l}\text { 9. SBDÖP'de } \\
\text { kazanımlar } \\
\text { rahatça } \\
\text { anlaşılabilir } \\
\text { şekilde açık-seçik } \\
\text { ifade edilmiştir. }\end{array}$} & Hiç Katılmıyorum & 2 & 1,2 & & \multirow{5}{*}{ Katıliyorum } \\
\hline & Kat1lmiyorum & 10 & 6,0 & & \\
\hline & $\begin{array}{l}\text { Kismen } \\
\text { Katiliyorum }\end{array}$ & 41 & 24,4 & 3,75 & \\
\hline & Katıliyorum & 90 & 53,6 & & \\
\hline & $\begin{array}{l}\text { Tamamen } \\
\text { Katıliyorum }\end{array}$ & 25 & 14,9 & & \\
\hline \multirow{5}{*}{$\begin{array}{l}\text { 10. Sosyal bilgiler } \\
\text { dersinde genel } \\
\text { kazanımlar } \\
\text { gerçekleştirilebil } \\
\text { mektedir. }\end{array}$} & Hiç Katılmıyorum & 0 & 0,0 & & \multirow{5}{*}{ Katıliyorum } \\
\hline & Katılmiyorum & 15 & 8,9 & & \\
\hline & $\begin{array}{l}\text { Kismen } \\
\text { Katiliyorum }\end{array}$ & 51 & 30,4 & 3,63 & \\
\hline & Katıliyorum & 83 & 49,4 & & \\
\hline & $\begin{array}{l}\text { Tamamen } \\
\text { Katıliyorum }\end{array}$ & 19 & 11,3 & & \\
\hline \multirow{5}{*}{$\begin{array}{l}\text { 11. Sosyal bilgiler } \\
\text { dersinde } \\
\text { kazanımlar } \\
\text { belirlenirken } \\
\text { ögrretmen } \\
\text { görüşlerine daha } \\
\text { önem } \\
\text { verilmektedir. }\end{array}$} & Hiç Katılmıyorum & 17 & 10,1 & & \multirow{5}{*}{$\begin{array}{l}\text { Kismen } \\
\text { Kat1liyorum }\end{array}$} \\
\hline & Katılmiyorum & 41 & 24,4 & & \\
\hline & $\begin{array}{l}\text { Kismen } \\
\text { Katıliyorum }\end{array}$ & 54 & 32,1 & 2,98 & \\
\hline & Katıliyorum & 41 & 24,4 & & \\
\hline & $\begin{array}{l}\text { Tamamen } \\
\text { Katıliyorum }\end{array}$ & 15 & 8,9 & & \\
\hline \multirow{5}{*}{$\begin{array}{l}\text { 12. Öğrencilerin } \\
\text { sosyal bilgiler } \\
\text { dersine olan ilgi } \\
\text { düzeyleri } \\
\text { programın } \\
\text { hedeflerinin } \\
\text { gerçekleştirilmesi } \\
\text { ni etkilemektedir. }\end{array}$} & Hiç Katılmıyorum & 2 & 1,2 & & \multirow{5}{*}{ Katıliyorum } \\
\hline & Katılmıyorum & 11 & 6,5 & & \\
\hline & $\begin{array}{l}\text { Kismen } \\
\text { Katıliyorum }\end{array}$ & 32 & 19,0 & 3,91 & \\
\hline & Katıliyorum & 78 & 46,4 & & \\
\hline & $\begin{array}{l}\text { Tamamen } \\
\text { Katıliyorum }\end{array}$ & 45 & 26,8 & & \\
\hline
\end{tabular}

Not=1., 5., 6. Maddeler ters yönde kodlanmaktadır. 
Tablo-2 incelendiğinde; öğretmenler SBDÖP'nin genel amaçlarının açık bir şekilde ifade edilmesi, SBDÖP'nin genel amaçlarının milli eğitimin temel amaçları ile uyuşması, SBDÖP'de benimsenen yaklaşımın bireyin toplumsal varoluşunu gerçekleştirmeye yönelik olması, sosyal bilgiler ders kitabında yer alan kavramların rahatça anlaşılabilir şekilde açık-seçik ifade edilmesi, SBDÖP'de kazanımların öğrencilerin sınıf düzeyine uygun olması, SBDÖP'de kazanımların öğrencilerin ihtiyaçlarına uygun tasarlanması, SBDÖP'de kazanımların birbirini desteklemesi, SBDÖP'de kazanımların rahatça anlaşılabilir şekilde açık-seçik ifade edilmesi, Sosyal bilgiler dersinde genel kazanımların gerçekleştirilebilmesi, sosyal bilgiler dersinde kazanımlar belirlenirken öğretmen görüşlerine daha önem verilmesi ve öğrencilerin sosyal bilgiler dersine olan ilgi düzeylerinin programın hedeflerinin gerçekleştirilmesini etkilemesi konularında olumlu görüş belirtmektedir. SBDÖP'de kullanılan yaklaşımların öğrencinin empati kurma yeteneğinin gelişmesine katkıda bulunması konusunda ise olumsuz görüş belirtmektedir.

\section{Programın Vizyonu Boyutuna Yönelik Bulgular}

Araştırmaya katılan öğretmenlerin anketin "Programın Vizyonu" boyutuna verdikleri yanıtların genel dağılımı ile ilgili bulgular Tablo 3'de verilmiştir.

Tablo 3. Araştırmaya Katılan Öğretmenlerin Anketin "Programın Vizyonu" Boyutuna Verdikleri Yanıtların Genel Dağıılımı ile İlgili Bulgular

\begin{tabular}{|c|c|c|c|c|c|}
\hline Anket Maddeleri & & $\mathbf{f}$ & $\%$ & $\bar{X}$ & Anlamı \\
\hline \multicolumn{6}{|l|}{ Programın Vizyonu } \\
\hline \multirow[t]{5}{*}{$\begin{array}{l}\text { 13. SBDÖP'nin vizyonu } \\
\text { açık bir şekilde ifade } \\
\text { edilmemiştir. }\end{array}$} & $\begin{array}{l}\text { Hiç } \\
\text { Katılmiyorum }\end{array}$ & 22 & 13,1 & \multirow{5}{*}{2,58} & \multirow{5}{*}{ Katılmiyorum } \\
\hline & Katilmiyorum & 69 & 41,1 & & \\
\hline & $\begin{array}{l}\text { Kismen } \\
\text { Katıliyorum }\end{array}$ & 38 & 22,6 & & \\
\hline & Katıliyorum & 35 & 20,8 & & \\
\hline & $\begin{array}{l}\text { Tamamen } \\
\text { Katıliyorum }\end{array}$ & 4 & 2,4 & & \\
\hline \multirow{4}{*}{$\begin{array}{l}\text { 14. SBDÖP'nin vizyonu } \\
\text { gerçekleştirmeye } \\
\text { yöneliktir. }\end{array}$} & $\begin{array}{l}\text { Hiç } \\
\text { Katılmıyorum }\end{array}$ & 2 & 1,2 & \multirow{4}{*}{3,60} & \multirow{4}{*}{ Katıliyorum } \\
\hline & Katılmiyorum & 11 & 6,5 & & \\
\hline & $\begin{array}{l}\text { Kismen } \\
\text { Kat1liyorum }\end{array}$ & 57 & 33,9 & & \\
\hline & Katıliyorum & 81 & 48,2 & & \\
\hline
\end{tabular}

http://dergipark.gov.tr/aicusbed 7/2 Ekim/October 2021 
Güncellenen 5. Sınıf Sosyal Bilgiler Öğretim Programının Öğretmen Görüşlerine Göre

Değerlendirilmesi | 37

\begin{tabular}{|c|c|c|c|c|c|}
\hline & $\begin{array}{l}\text { Tamamen } \\
\text { Kat1liyorum }\end{array}$ & 17 & 10,1 & & \\
\hline \multirow{7}{*}{$\begin{array}{l}\text { 15. SBDÖP'nin vizyonu } \\
\text { çağımızın gerektirdiği } \\
\text { insanın sahip olması } \\
\text { gereken donanımı ifade } \\
\text { etmektedir. }\end{array}$} & Hiç & 2 & 1.2 & \multirow{7}{*}{3,63} & \multirow{7}{*}{ Katıliyorum } \\
\hline & Katılmıyorum & 2 & 1,2 & & \\
\hline & Katılmiyorum & 13 & 7,7 & & \\
\hline & Kismen & 54 & 32,1 & & \\
\hline & Katıliyorum & 54 & 32,1 & & \\
\hline & Katıliyorum & 76 & 45,2 & & \\
\hline & $\begin{array}{l}\text { Tamamen } \\
\text { Katıliyorum }\end{array}$ & 23 & 13,7 & & \\
\hline
\end{tabular}

Not $=13$. madde ters yönde kodlanmaktadır.

Tablo-3 incelendiğinde; öğretmenler SBDÖP'nin vizyonunun açık bir şekilde ifade edilmesi, gerçekleştirmeye yönelik olması ve çağımızın gerektirdiği insanın sahip olması gereken donanımı ifade etmesi konusunda olumlu görüş belirtmektedir.

\section{Programın İçeriği Boyutuna Yönelik Bulgular}

Araştırmaya katılan öğretmenlerin anketin "Programın İçeriğì" boyutuna verdikleri yanıtların genel dağılımı ile ilgili bulgular Tablo 4'de verilmiştir.

Tablo 4. Araştırmaya Katılan Öğretmenlerin Anketin "Programın İçeriği" Boyutuna Verdikleri Yanıtların Genel Dağılımı ile İlgili Bulgular

\begin{tabular}{|c|c|c|c|c|c|}
\hline Anket Maddeleri & & $\mathbf{f}$ & $\%$ & $\bar{X}$ & Anlamı \\
\hline \multicolumn{6}{|l|}{ Programın İçeriği } \\
\hline \multirow{4}{*}{$\begin{array}{l}\text { 16. İçerik genel amaçlara } \\
\text { ulaşmayı sağlayacak } \\
\text { niteliktedir. }\end{array}$} & $\begin{array}{l}\text { Hiç } \\
\text { Katılmıyorum }\end{array}$ & 2 & 1,2 & \multirow{4}{*}{3,73} & \multirow{4}{*}{ Katıliyorum } \\
\hline & Katılmıyorum & 8 & 4,8 & & \\
\hline & $\begin{array}{l}\text { Kismen } \\
\text { Katiliyorum }\end{array}$ & 43 & 25,6 & & \\
\hline & $\begin{array}{l}\text { Katıliyorum } \\
\text { Tamamen } \\
\text { Katıliyorum } \\
\end{array}$ & 19 & $\begin{array}{l}57,1 \\
11,3 \\
\end{array}$ & & \\
\hline \multirow{2}{*}{$\begin{array}{l}\text { 17. SBDÖP'yi oluşturan } \\
\text { temel öğeler beceri, } \\
\text { kavram, değer ve genel } \\
\text { amaçlar programda } \\
\text { rahatça anlaşllabilir }\end{array}$} & $\begin{array}{l}\text { Hiç } \\
\text { Katılmıyorum }\end{array}$ & 2 & 1,2 & \multirow[b]{2}{*}{3,61} & \multirow[b]{2}{*}{ Kat1liyorum } \\
\hline & $\begin{array}{l}\text { Katılmiyorum } \\
\text { Kismen } \\
\text { Katıliyorum }\end{array}$ & 12 & $\begin{array}{c}7,1 \\
31,5\end{array}$ & & \\
\hline
\end{tabular}

http://dergipark.gov.tr/aicusbed 7/2 Ekim / October 2021 


\begin{tabular}{|c|c|c|c|c|c|}
\hline $\begin{array}{l}\text { şekilde açık-seçik ifade } \\
\text { edilmiştir. }\end{array}$ & $\begin{array}{l}\text { Katıliyorum } \\
\text { Tamamen } \\
\text { Katıliyorum } \\
\end{array}$ & $\begin{array}{l}84 \\
17 \\
\end{array}$ & 10,1 & & \\
\hline $\begin{array}{l}\text { 18. SBDÖP, öğrencilerin } \\
\text { kendine özgü becerileri }\end{array}$ & $\begin{array}{l}\text { Hiç } \\
\text { Katılmiyorum }\end{array}$ & 3 & 1,8 & \multirow{4}{*}{3,60} & \multirow{4}{*}{ Katıliyorum } \\
\hline $\begin{array}{l}\text { kazanmasinda etkin bir } \\
\text { rol oynamaktadır. }\end{array}$ & Katılmıyorum & 12 & 7,1 & & \\
\hline & $\begin{array}{l}\text { Kismen } \\
\text { Katıliyorum }\end{array}$ & 53 & 31,5 & & \\
\hline & $\begin{array}{l}\text { Katıliyorum } \\
\text { Tamamen } \\
\text { Kat1liyorum }\end{array}$ & 18 & 10,7 & & \\
\hline \multirow{3}{*}{$\begin{array}{l}\text { 19. SBDÖP'de yer alan } \\
\text { kavramlar öğrencilerin } \\
\text { seviyesine uygun } \\
\text { değildir. }\end{array}$} & $\begin{array}{l}\text { Hiç } \\
\text { Katılmıyorum }\end{array}$ & 32 & 19,0 & \multirow{3}{*}{2,39} & \multirow{3}{*}{ Katılmiyorum } \\
\hline & $\begin{array}{l}\text { Katılmiyorum } \\
\text { Kismen } \\
\text { Katıliyorum }\end{array}$ & 65 & 28,0 & & \\
\hline & $\begin{array}{l}\text { Katıliyorum } \\
\text { Tamamen } \\
\text { Kat1liyorum }\end{array}$ & 21 & 12,5 & & \\
\hline \multirow{4}{*}{$\begin{array}{l}\text { 20. Sosyal bilgiler ders } \\
\text { kitabında kullanılan } \\
\text { kavram haritaları } \\
\text { sayesinde konu daha iyi } \\
\text { anlaşılmaktadır. }\end{array}$} & $\begin{array}{l}\text { Hiç } \\
\text { Katılmıyorum }\end{array}$ & 1 & 6 & \multirow{4}{*}{3,78} & \multirow{4}{*}{ Katıliyorum } \\
\hline & Katılmiyorum & 9 & 5,4 & & \\
\hline & $\begin{array}{l}\text { Kismen } \\
\text { Katiliyorum }\end{array}$ & 41 & 24,4 & & \\
\hline & $\begin{array}{l}\text { Katıliyorum } \\
\text { Tamamen } \\
\text { Katıliyorum }\end{array}$ & 25 & 14,9 & & \\
\hline \multirow{4}{*}{$\begin{array}{l}\text { 21. SBDÖP, öğrencilerin } \\
\text { kendi değer sistemlerini } \\
\text { kurmada etkin bir rol } \\
\text { oynamaktadır. }\end{array}$} & $\begin{array}{l}\text { Hiç } \\
\text { Katılmıyorum }\end{array}$ & 1 & 6 & \multirow{4}{*}{3,76} & \multirow{4}{*}{ Katıliyorum } \\
\hline & $\begin{array}{l}\text { Katılmiyorum } \\
\text { Kismen } \\
\text { Katıliyorum }\end{array}$ & 41 & 24,4 & & \\
\hline & Katıliyorum & 92 & 54,8 & & \\
\hline & $\begin{array}{l}\text { Tamamen } \\
\text { Katıliyorum }\end{array}$ & 24 & 14,3 & & \\
\hline \multirow{2}{*}{$\begin{array}{l}\text { 22. SBDÖP, öğrencileri } \\
\text { araştırma ve incelemeye } \\
\text { sevk etmektedir. }\end{array}$} & $\begin{array}{l}\text { Hiç } \\
\text { Katılmıyorum }\end{array}$ & 1 & ,6 & & \\
\hline & Katılmiyorum & 17 & 10,1 & & \\
\hline
\end{tabular}

http://dergipark.gov.tr/aicusbed 7/2 Ekim /October 2021 
Güncellenen 5. Sınıf Sosyal Bilgiler Öğretim Programının Öğretmen Görüşlerine Göre

Değerlendirilmesi | 39

\begin{tabular}{|c|c|c|c|c|c|}
\hline & $\begin{array}{l}\text { Kismen } \\
\text { Katiliyorum }\end{array}$ & 51 & 30,4 & 3,56 & Katıliyorum \\
\hline & Katılıyorum & 85 & 50,6 & & \\
\hline & $\begin{array}{l}\text { Tamamen } \\
\text { Katıliyorum }\end{array}$ & 14 & 8,3 & & \\
\hline \multirow{5}{*}{$\begin{array}{l}\text { 23. SBDÖP'nin içeriği } \\
\text { somuttan soyuta olacak } \\
\text { şekilde düzenlenmemiştir. }\end{array}$} & $\begin{array}{l}\text { Hiç } \\
\text { Katılmıyorum }\end{array}$ & 16 & 9,5 & \multirow{5}{*}{2,83} & \multirow{5}{*}{$\begin{array}{l}\text { Kismen } \\
\text { Kat1liyorum }\end{array}$} \\
\hline & Katılmıyorum & 55 & 32,7 & & \\
\hline & $\begin{array}{l}\text { Kismen } \\
\text { Katiliyorum }\end{array}$ & 43 & 25,6 & & \\
\hline & Katıliyorum & 49 & 29,2 & & \\
\hline & $\begin{array}{l}\text { Tamamen } \\
\text { Katiliyorum }\end{array}$ & 5 & 3,0 & & \\
\hline \multirow{5}{*}{$\begin{array}{l}\text { 24. SBDÖP'nin içeriği } \\
\text { geçmişte öğretilen } \\
\text { konuları } \\
\text { desteklemektedir. }\end{array}$} & $\begin{array}{l}\text { Hiç } \\
\text { Katılmıyorum }\end{array}$ & 1 & ,6 & \multirow{5}{*}{3,73} & \multirow{5}{*}{ Katıliyorum } \\
\hline & Katılmiyorum & 10 & 6,0 & & \\
\hline & $\begin{array}{l}\text { Kismen } \\
\text { Katiliyorum }\end{array}$ & 50 & 29,8 & & \\
\hline & Katıliyorum & 80 & 47,6 & & \\
\hline & $\begin{array}{l}\text { Tamamen } \\
\text { Katiliyorum }\end{array}$ & 27 & 16,1 & & \\
\hline \multirow{5}{*}{$\begin{array}{l}\text { 25. SBDÖP, diğer ders } \\
\text { programlarıly } \\
\text { desteklenmektedir. }\end{array}$} & $\begin{array}{l}\text { Hiç } \\
\text { Katılmıyorum }\end{array}$ & 1 & ,6 & \multirow{5}{*}{3,70} & \multirow{5}{*}{ Katıliyorum } \\
\hline & Katılmıyorum & 8 & 4,8 & & \\
\hline & $\begin{array}{l}\text { Kismen } \\
\text { Katiliyorum }\end{array}$ & 51 & 30,4 & & \\
\hline & Katıliyorum & 88 & 52,4 & & \\
\hline & $\begin{array}{l}\text { Tamamen } \\
\text { Katiliyorum }\end{array}$ & 20 & 11,9 & & \\
\hline \multirow{4}{*}{$\begin{array}{l}\text { 26. SBDÖP'nin içeriği, } \\
\text { benimsenen temel } \\
\text { yaklaşımın uygulanmasını } \\
\text { gerçekleştirebilmektedir. }\end{array}$} & $\begin{array}{l}\text { Hiç } \\
\text { Katılmıyorum }\end{array}$ & 1 & ,6 & \multirow{4}{*}{3,65} & \multirow{4}{*}{ Katılıyorum } \\
\hline & Katılmıyorum & 8 & 4,8 & & \\
\hline & $\begin{array}{l}\text { Kismen } \\
\text { Katiliyorum }\end{array}$ & 56 & 33,3 & & \\
\hline & Katıliyorum & 87 & 51,8 & & \\
\hline
\end{tabular}

http://dergipark.gov.tr/aicusbed 7/2 Ekim / October 2021 


\begin{tabular}{|c|c|c|c|c|c|}
\hline & $\begin{array}{l}\text { Tamamen } \\
\text { Katiliyorum }\end{array}$ & 16 & 9,5 & & \\
\hline \multirow{5}{*}{$\begin{array}{l}\text { 27. SBDÖP'yi alan } \\
\text { öğrenciler çalışkan, } \\
\text { araştırıcı, özverili, } \\
\text { erdemli ve girişimci bir } \\
\text { yapıya sahip olurlar. }\end{array}$} & $\begin{array}{l}\text { Hiç } \\
\text { Katılmıyorum }\end{array}$ & 2 & 1,2 & \multirow{5}{*}{3,69} & \multirow{5}{*}{ Katıliyorum } \\
\hline & Katılmıyorum & 8 & 4,8 & & \\
\hline & $\begin{array}{l}\text { Kismen } \\
\text { Katıliyorum }\end{array}$ & 52 & 31,0 & & \\
\hline & Katıliyorum & 84 & 50,0 & & \\
\hline & $\begin{array}{l}\text { Tamamen } \\
\text { Katıliyorum }\end{array}$ & 22 & 13,1 & & \\
\hline \multirow{5}{*}{$\begin{array}{l}\text { 28. SBDÖP'yi alan } \\
\text { öğrenciler ailelerine, } \\
\text { vatanına, Atatürk ilke ve } \\
\text { inkılaplarına bağlı } \\
\text { insanlar olarak yetişirler. }\end{array}$} & $\begin{array}{l}\text { Hiç } \\
\text { Katılmıyorum }\end{array}$ & 2 & 1,2 & \multirow{5}{*}{3,93} & \multirow{5}{*}{ Kat1liyorum } \\
\hline & Katılmiyorum & 5 & 3,0 & & \\
\hline & $\begin{array}{l}\text { Kismen } \\
\text { Katıliyorum }\end{array}$ & 37 & 22,0 & & \\
\hline & Katıliyorum & 83 & 49,4 & & \\
\hline & $\begin{array}{l}\text { Tamamen } \\
\text { Katıliyorum }\end{array}$ & 41 & 24,4 & & \\
\hline \multirow{4}{*}{$\begin{array}{l}\text { 29. SBDÖP'yi alan } \\
\text { öğrenciler, Türk } \\
\text { toplumunun birer üyesi } \\
\text { olarak görev ve } \\
\text { sorumluluk alabilecek } \\
\text { hale gelirler. }\end{array}$} & $\begin{array}{l}\text { Hiç } \\
\text { Katılmıyorum }\end{array}$ & 3 & 1,8 & \multirow{4}{*}{3,96} & \multirow{4}{*}{ Katıliyorum } \\
\hline & $\begin{array}{l}\text { Katılmıyorum } \\
\text { Kismen } \\
\text { Katıliyorum }\end{array}$ & 38 & 22,6 & & \\
\hline & Katılıyorum & 83 & 49,4 & & \\
\hline & $\begin{array}{l}\text { Tamamen } \\
\text { Katıliyorum }\end{array}$ & 43 & 25,6 & & \\
\hline \multirow{6}{*}{$\begin{array}{l}\text { 30. SBDÖP’yi alan } \\
\text { öğrenciler, aile } \\
\text { bütünlüğüne bağlılık } \\
\text { kazanır, ailenin refah ve } \\
\text { mutluluğu için } \\
\text { sorumluluk ve görev } \\
\text { duygularını geliştirirler. }\end{array}$} & $\begin{array}{l}\text { Hiç } \\
\text { Katılmıyorum }\end{array}$ & 3 & 1,8 & \multirow{4}{*}{3,93} & \multirow{4}{*}{ Katıliyorum } \\
\hline & $\begin{array}{l}\text { Katılmiyorum } \\
\text { Kismen } \\
\text { Kat1liyorum }\end{array}$ & 35 & 20,8 & & \\
\hline & Katıliyorum & 92 & 54,8 & & \\
\hline & $\begin{array}{l}\text { Tamamen } \\
\text { Katıliyorum }\end{array}$ & 36 & 21,4 & & \\
\hline & $\begin{array}{l}\text { Hiç } \\
\text { Katılmıyorum }\end{array}$ & 3 & 1,8 & & \\
\hline & Katılmiyorum & 9 & 5,4 & & \\
\hline
\end{tabular}

http://dergipark.gov.tr/aicusbed 7/2 Ekim/October 2021 
Güncellenen 5. Sınıf Sosyal Bilgiler Öğretim Programının Öğretmen Görüşlerine Göre

Değerlendirilmesi 41

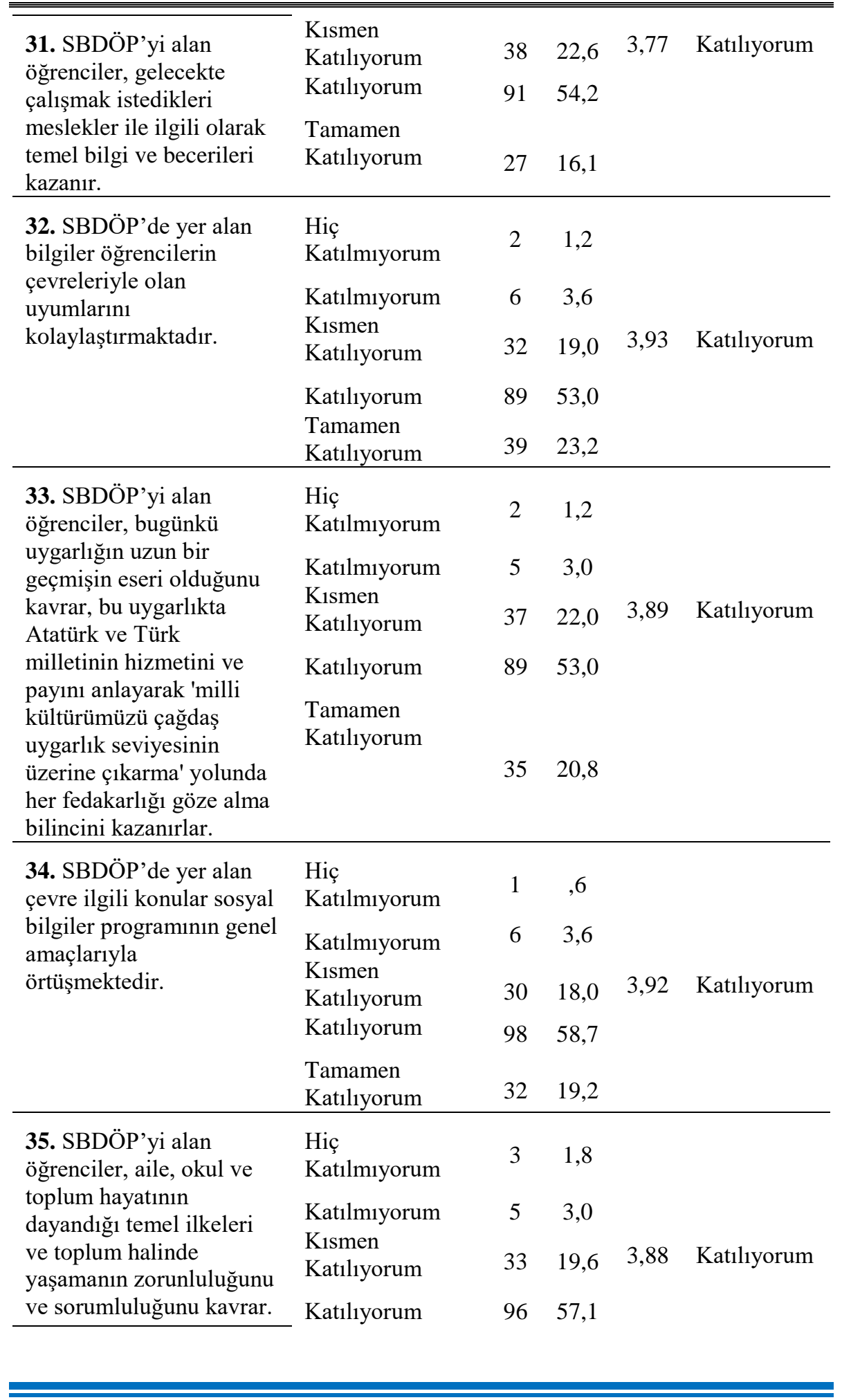

http://dergipark.gov.tr/aicusbed 7/2 Ekim / October 2021 


\begin{tabular}{|c|c|c|c|c|c|}
\hline & $\begin{array}{l}\text { Tamamen } \\
\text { Katıliyorum }\end{array}$ & 31 & 18,5 & & \\
\hline \multirow{5}{*}{$\begin{array}{l}\text { 36. SBDÖP, öğrencilerin } \\
\text { gelecekteki yaşantılarına } \\
\text { 1şık tutarak bireylerden } \\
\text { beklenen niteliklerin } \\
\text { gelişmesine yardımcı } \\
\text { olur. }\end{array}$} & $\begin{array}{l}\text { Hiç } \\
\text { Katılmıyorum }\end{array}$ & 2 & 1,2 & \multirow{5}{*}{3,82} & \multirow{5}{*}{ Kat1liyorum } \\
\hline & Katılmiyorum & 7 & 4,2 & & \\
\hline & $\begin{array}{l}\text { Kismen } \\
\text { Kat1liyorum }\end{array}$ & 40 & 23,8 & & \\
\hline & Kat1liyorum & 89 & 53,0 & & \\
\hline & $\begin{array}{l}\text { Tamamen } \\
\text { Kat1liyorum }\end{array}$ & 30 & 17,9 & & \\
\hline \multirow{5}{*}{$\begin{array}{l}\text { 37. SBDÖP, bir bütün } \\
\text { olarak amaçlandığı temel } \\
\text { düşünceleri } \\
\text { kazandırmaktadır. }\end{array}$} & $\begin{array}{l}\text { Hiç } \\
\text { Katılmıyorum }\end{array}$ & 1 & ,6 & \multirow{5}{*}{3,83} & \multirow{5}{*}{ Katıliyorum } \\
\hline & Katılmiyorum & 10 & 6,0 & & \\
\hline & $\begin{array}{l}\text { Kismen } \\
\text { Kat1liyorum }\end{array}$ & 33 & 19,6 & & \\
\hline & Kat1liyorum & 97 & 57,7 & & \\
\hline & $\begin{array}{l}\text { Tamamen } \\
\text { Katıliyorum }\end{array}$ & 27 & 16,1 & & \\
\hline
\end{tabular}

Not= 19., 23. maddeler ters yönde kodlanmaktadır.

Tablo-4 incelendiğinde; öğretmenler içeriğin genel amaçlara ulaşmayı sağlayacak nitelikte olması, SBDÖP'yi oluşturan temel öğeler beceri, kavram, değer ve genel amaçların programda rahatça anlaşılabilir şekilde açık-seçik ifade edilmesi, SBDÖP'nin öğrencilerin kendine özgü becerileri kazanmasında etkin bir rol oynaması, SBDÖP'de yer alan kavramların öğrencilerin seviyesine uygun olması konusunda olumlu görüş bildirmişlerdir. Sosyal bilgiler ders kitabında kullanılan kavram haritaları sayesinde konuların daha iyi anlaşılmakta olduğu, SBDÖP'nin öğrencilerin kendi değer sistemlerini kurmada etkin bir rol oynaması ve öğrencileri araştırma ve incelemeye sevk etmesi, SBDÖP'nin içeriğinin geçmişte öğretilen konuları desteklemesi, konusunda öğretmenlerin olumlu görüşte oldukları tespit edilmiştir. SBDÖP'nin diğer ders programlarıyla desteklenmesi, SBDÖP'nin içeriğinin, benimsenen temel yaklaşımın uygulanmasını gerçekleştirebilmesi, SBDÖP'yi alan öğrencilerin çalışkan, araştırıcı, özverili, erdemli ve girişimci bir yapıya sahip olması, vatanına, Atatürk ilke ve inkılaplarına bağlı insanlar olarak yetişmesi, Türk toplumunun birer üyesi olarak görev ve sorumluluk alabilecek hale gelmesi, aile bütünlüğüne bağl1lık kazanması, ailenin refah ve mutluluğu için sorumluluk ve görev duygularını geliştirmesi ve gelecekte çalışmak istedikleri meslekler ile ilgili olarak temel bilgi ve becerileri kazanması, hususunda öğretmenlerin 
görüşleri olumludur. SBDÖP'de yer alan bilgilerin öğrencilerin çevreleriyle olan uyumlarını kolaylaştırması, SBDÖP'yi alan öğrencilerin, bugünkü uygarlığın uzun bir geçmişin eseri olduğunu kavrar, bu uygarlıkta Atatürk ve Türk milletinin hizmetini ve payını anlayarak 'milli kültürümüzü çağdaş uygarlık seviyesinin üzerine çıkarma' yolunda her fedakarlı̆̆ göze alma bilincini kazanması, konularında görüşleri olumludur. SBDÖP'de yer alan çevre ilgili konuların sosyal bilgiler programının genel amaçlarıla örtüşmekte oluşu, SBDÖP'yi alan öğrencilerin, aile, okul ve toplum hayatının dayandığı temel ilkeleri ve toplum halinde yaşamanın zorunluluğunu ve sorumluluğunu kavraması, SBDÖP'nin öğrencilerin gelecekteki yaşantılarına 1ş1k tutarak bireylerden beklenen niteliklerin gelişmesine yardımcı olması, SBDÖP'nin bir bütün olarak amaçlandığı temel düşünceleri kazandırması konularında olumlu görüş belirtmektedirler. SBDÖP'nin içeriğinin somuttan soyuta olacak şekilde düzenlenmesi konusunda ise olumsuz görüş belirmişlerdir.

\section{Programın Öğrenme Öğretme Süreci Boyutuna Yönelik Bulgular}

Araştırmaya katılan öğretmenlerin anketin "Öğrenme Öğretme Süreci” boyutuna verdikleri yanıtların genel dağılımı ile ilgili bulgular Tablo 5'de verilmiştir.

Tablo 5. Araştırmaya Katılan Öğretmenlerin Anketin "Öğrenme Öğretme Süreci" Boyutuna Verdikleri Yanıtların Genel Dağılımı ile İlgili Bulgular

\begin{tabular}{|c|c|c|c|c|c|}
\hline Anket Maddeleri & & f & $\%$ & $\bar{X}$ & Anlamı \\
\hline \multicolumn{6}{|l|}{ Öğrenme Öğretme Süreci } \\
\hline \multirow{5}{*}{$\begin{array}{l}\text { 38. Sosyal bilgiler } \\
\text { dersinde kullanılması } \\
\text { önerilen öğretim yöntem } \\
\text { ve teknikleri öğrencileri } \\
\text { bilgi ve becerilerini } \\
\text { yeniden yapılandırarak } \\
\text { hayata geçirmelerine } \\
\text { olanak sağlamaktadır. }\end{array}$} & $\begin{array}{l}\text { Hiç } \\
\text { Katılmıyorum }\end{array}$ & 2 & 1,2 & \multirow{5}{*}{3,69} & \multirow{5}{*}{ Katıliyorum } \\
\hline & Katılmıyorum & 6 & 3,6 & & \\
\hline & $\begin{array}{l}\text { Kismen } \\
\text { Kat1liyorum }\end{array}$ & 49 & 29,2 & & \\
\hline & Katıliyorum & 96 & 57,1 & & \\
\hline & $\begin{array}{l}\text { Tamamen } \\
\text { Katıllyorum }\end{array}$ & 15 & 8,9 & & \\
\hline \multirow{3}{*}{$\begin{array}{l}\text { 39. SBDÖP'nin } \\
\text { ügulanmasinda } \\
\text { öğretmen yol gösterici, }\end{array}$} & $\begin{array}{l}\text { Hiç } \\
\text { Katılmıyorum }\end{array}$ & 1 & ,6 & & \\
\hline & Katılmiyorum & 11 & 6,5 & & \multirow[b]{2}{*}{ Katıliyorum } \\
\hline & $\begin{array}{l}\text { Kismen } \\
\text { Kat1liyorum }\end{array}$ & 36 & 21,4 & 3,77 & \\
\hline
\end{tabular}

http://dergipark.gov.tr/aicusbed 7/2 Ekim / October 2021 


\begin{tabular}{|c|c|c|c|c|c|}
\hline $\begin{array}{l}\text { öğrenci ise aktif } \\
\text { durumdadır. }\end{array}$ & $\begin{array}{l}\text { Katıliyorum } \\
\text { Tamamen } \\
\text { Katıliyorum }\end{array}$ & $\begin{array}{l}98 \\
22 \\
\end{array}$ & $\begin{array}{l}58,3 \\
13,1 \\
\end{array}$ & & \\
\hline \multirow{5}{*}{$\begin{array}{l}\text { 40. SBDÖP'de modern } \\
\text { ögretim yöntem ve } \\
\text { tekniklerine yeterince } \\
\text { yer verilmemektedir. }\end{array}$} & $\begin{array}{l}\text { Hiç } \\
\text { Katılmıyorum }\end{array}$ & 21 & 12,5 & \multirow{5}{*}{2,60} & \multirow{5}{*}{ Katılmıyorum } \\
\hline & Katılmıyorum & 61 & 36,3 & & \\
\hline & $\begin{array}{l}\text { Kismen } \\
\text { Kat1liyorum }\end{array}$ & 52 & 31,0 & & \\
\hline & Katıliyorum & 32 & 19,0 & & \\
\hline & $\begin{array}{l}\text { Tamamen } \\
\text { Katıllyorum }\end{array}$ & 2 & 1,2 & & \\
\hline \multirow{5}{*}{$\begin{array}{l}\text { 41. SBDÖP'de ünitelerin } \\
\text { işlenişi sırasında } \\
\text { öğretmenlerin } \\
\text { kullanacağı yeterli } \\
\text { uygulama örnekleri } \\
\text { bulunmamaktadır. }\end{array}$} & $\begin{array}{l}\text { Hiç } \\
\text { Katılmıorum }\end{array}$ & 21 & 12,5 & \multirow{5}{*}{2,77} & \multirow{5}{*}{$\begin{array}{l}\text { Kismen } \\
\text { Kat1liyorum }\end{array}$} \\
\hline & Katılmiyorum & 51 & 30,4 & & \\
\hline & $\begin{array}{l}\text { Kismen } \\
\text { Kat1liyorum }\end{array}$ & 49 & 29,2 & & \\
\hline & Katıliyorum & 40 & 23,8 & & \\
\hline & $\begin{array}{l}\text { Tamamen } \\
\text { Katıliyorum }\end{array}$ & 7 & 4,2 & & \\
\hline \multirow{5}{*}{$\begin{array}{l}\text { 42. Sosyal bilgiler } \\
\text { dersinde öğrencilere } \\
\text { yapıci-yaratıcı } \\
\text { faaliyetlere yöneltecek } \\
\text { etkinlikler } \\
\text { yapılmaktadır. }\end{array}$} & $\begin{array}{l}\text { Hiç } \\
\text { Katılmıyorum }\end{array}$ & 4 & 2,4 & \multirow{5}{*}{3,47} & \multirow{5}{*}{ Katıliyorum } \\
\hline & Katılmiyorum & 17 & 10,1 & & \\
\hline & $\begin{array}{l}\text { Kismen } \\
\text { Katıliyorum }\end{array}$ & 57 & 33,9 & & \\
\hline & Katıliyorum & 76 & 45,2 & & \\
\hline & $\begin{array}{l}\text { Tamamen } \\
\text { Katılıyorum }\end{array}$ & 14 & 8,3 & & \\
\hline \multirow{5}{*}{$\begin{array}{l}\text { 43. SBDÖP'de } \\
\text { yapılması tasarlanan } \\
\text { etkinlikler öğrencilerin } \\
\text { gelişim özelliklerine } \\
\text { uygundur. }\end{array}$} & $\begin{array}{l}\text { Hiç } \\
\text { Katılmıyorum }\end{array}$ & 2 & 1,2 & \multirow{5}{*}{3,72} & \multirow{5}{*}{ Kat1liyorum } \\
\hline & Katılmıyorum & 8 & 4,8 & & \\
\hline & $\begin{array}{l}\text { Kismen } \\
\text { Kat1liyorum }\end{array}$ & 46 & 27,4 & & \\
\hline & Katıliyorum & 91 & 54,2 & & \\
\hline & $\begin{array}{l}\text { Tamamen } \\
\text { Katıliyorum }\end{array}$ & 21 & 12,5 & & \\
\hline \multirow{3}{*}{$\begin{array}{l}\text { 44. SBDÖP, yapılması } \\
\text { gereken etkinliklerde } \\
\text { öğrencilere yol } \\
\text { gösterebilmektedir }\end{array}$} & $\begin{array}{l}\text { Hiç } \\
\text { Katılmıyorum }\end{array}$ & 1 & .6 & \multirow[b]{3}{*}{3,77} & \multirow[b]{3}{*}{ Katıliyorum } \\
\hline & $\begin{array}{l}\text { Katılmiyorum } \\
\text { Kismen }\end{array}$ & 6 & 3,6 & & \\
\hline & Katıliyorum & 42 & 25,0 & & \\
\hline
\end{tabular}

http://dergipark.gov.tr/aicusbed 7/2 Ekim /October 2021 


\begin{tabular}{|c|c|c|c|c|c|}
\hline & Katıliyorum & 100 & 59,5 & & \\
\hline & $\begin{array}{l}\text { Tamamen } \\
\text { Katiliyorum }\end{array}$ & 19 & 11,3 & & \\
\hline \multirow{5}{*}{$\begin{array}{l}\text { 45. SBDÖP, yapılmas1 } \\
\text { gereken etkinliklerde } \\
\text { öğretmenlere yol } \\
\text { gösterebilmektedir. }\end{array}$} & $\begin{array}{l}\text { Hiç } \\
\text { Katılmıyorum }\end{array}$ & 4 & 2,4 & \multirow{5}{*}{3,75} & \multirow{5}{*}{ Katılıyorum } \\
\hline & Katılmiyorum & 5 & 3,0 & & \\
\hline & $\begin{array}{l}\text { Kismen } \\
\text { Kat1liyorum }\end{array}$ & 44 & 26,2 & & \\
\hline & Katıliyorum & 91 & 54,2 & & \\
\hline & $\begin{array}{l}\text { Tamamen } \\
\text { Katıliyorum }\end{array}$ & 24 & 14,3 & & \\
\hline
\end{tabular}

Not $=40,41 .$. maddeleri ters yönde kodlanmaktadır.

Tablo-5 incelendiğinde; öğretmenler sosyal bilgiler dersinde kullanılması önerilen öğretim yöntem ve teknikleri öğrencilerin bilgi ve becerilerini yeniden yapılandırarak hayata geçirmelerine olanak sağlaması, SBDÖP'nin uygulanmasında öğretmenin yol gösterici, öğrencinin ise aktif durumda olması, SBDÖP'de modern öğretim yöntem ve tekniklerine yeterince yer verilmesi, sosyal bilgiler dersinde öğrencilere yapıc1-yaratıcı faaliyetlere yöneltecek etkinlikler yapılmakta olduğu, SBDÖP'de tasarlanan etkinlikler öğrencilerin gelişim özelliklerine uygun olması, SBDÖP'nin yapılması gereken etkinliklerde öğrencilere ve öğretmenlere yol gösterebilmesi konularında olumlu görüş belirmiştir. SBDÖP'de ünitelerin işlenişi sırasında öğretmenlerin kullanacağı yeterli uygulama örnekleri bulunması konusunda ise olumsuz görüş belirtmişlerdir.

\section{Programın Ölçme ve Değerlendirme Boyutuna Yönelik Bulgular}

Araştırmaya katılan öğretmenlerin anketin "Ölçme ve Değerlendirme" boyutuna verdikleri yanıtların genel dağılımı ile ilgili bulgular Tablo 6'da verilmiştir.

Tablo 6: Araştırmaya Katılan Öğretmenlerin Anketin "Ölçme ve Değerlendirme" Boyutuna Verdikleri Yanıtların Genel Dağıılımı ile İlgili Bulgular

\begin{tabular}{llllll}
\hline \multicolumn{1}{c}{ Anket Maddeleri } & f & $\%$ & $\bar{X}$ & Anlamı \\
\hline Ölçme ve Değerlendirme & & & & & \\
\hline 46. SBDÖP, & Hiç & & & \\
öğretmenlerin ölçme & Katılmıorum & 2 & 1,2 & \\
& & & & \\
& & & \\
\hline \hline
\end{tabular}

http://dergipark.gov.tr/aicusbed 7/2 Ekim / October 2021 


\begin{tabular}{|c|c|c|c|c|c|}
\hline \multirow{3}{*}{$\begin{array}{l}\text { araçları geliştirmesi } \\
\text { açısından yol gösterici } \\
\text { olmaktadır. }\end{array}$} & Katılmıyorum & 8 & 4,8 & \multirow{3}{*}{3,64} & \multirow{3}{*}{ Katıliyorum } \\
\hline & $\begin{array}{l}\text { Kismen } \\
\text { Kat1liyorum }\end{array}$ & 54 & 32,1 & & \\
\hline & $\begin{array}{l}\text { Katıliyorum } \\
\text { Tamamen } \\
\text { Kat1liyorum }\end{array}$ & 15 & 8,9 & & \\
\hline \multirow{3}{*}{$\begin{array}{l}\text { 47. SBDÖP'de } \\
\text { değerlendirme işleminin } \\
\text { yapılabilmesi için gerekli } \\
\text { ölçütlere yer } \\
\text { verilmemiştir. }\end{array}$} & $\begin{array}{l}\text { Hiç } \\
\text { Katılmıyorum }\end{array}$ & 20 & 11,9 & \multirow{3}{*}{2,60} & \multirow{3}{*}{ Katılmiyorum } \\
\hline & $\begin{array}{l}\text { Katılmiyorum } \\
\text { Kismen } \\
\text { Kat1liyorum }\end{array}$ & 45 & 26,8 & & \\
\hline & $\begin{array}{l}\text { Katıliyorum } \\
\text { Tamamen } \\
\text { Katıliyorum } \\
\end{array}$ & 29 & 3,6 & & \\
\hline \multirow{3}{*}{$\begin{array}{l}\text { 48. SBDÖP'de } \\
\text { öğrencilerin yapmış } \\
\text { oldukları etkinliklerin } \\
\text { değerlendirilebilmesi } \\
\text { amacıyla öğretmenlere } \\
\text { rehberlik yapacak } \\
\text { açıklamalara yer } \\
\text { verilmiştir. }\end{array}$} & $\begin{array}{l}\text { Hiç } \\
\text { Katılmiyorum }\end{array}$ & 4 & 2,4 & \multirow{3}{*}{3,51} & \multirow{3}{*}{ Katıliyorum } \\
\hline & $\begin{array}{l}\text { Katılmiyorum } \\
\text { Kismen } \\
\text { Katıliyorum }\end{array}$ & 14 & 31,5 & & \\
\hline & $\begin{array}{l}\text { Katıliyorum } \\
\text { Tamamen } \\
\text { Kat1liyorum }\end{array}$ & 86 & 51,2 & & \\
\hline
\end{tabular}

Not $=47$. maddesi ters yönde kodlanmıştır.

Tablo-6 incelendiğinde; öğretmenler SBDÖP'nin öğretmenlerin ölçme araçları geliştirmesi açısından yol gösterici olması, SBDÖP'de değerlendirme işleminin yapılabilmesi için gerekli ölçütlere yer verilmesi ve öğrencilerin yapmış oldukları etkinliklerin değerlendirilebilmesi amacıyla öğretmenlere rehberlik yapacak açıklamalara yer verilmesi konularında olumlu görüş belirtmektedir.

\section{Programın Uygulama Boyutuna Yönelik Bulgular}

Araştırmaya katılan öğretmenlerin anketin "Uygulama Boyutu" boyutuna verdikleri yanıtların genel dağılımı ile ilgili bulgular Tablo 7'de verilmiştir. 
Güncellenen 5. Sınıf Sosyal Bilgiler Öğretim Programının Öğretmen Görüşlerine Göre

Değerlendirilmesi 47

Tablo 7. Araştırmaya Katılan Öğretmenlerin Anketin "Uygulama Boyutu” Boyutuna Verdikleri Yanıtların Genel Dağılımı ile İlgili Bulgular

\begin{tabular}{|c|c|c|c|c|c|}
\hline Anket Maddeleri & & f & $\%$ & $\bar{X}$ & Anlamı \\
\hline \multicolumn{6}{|l|}{ Uygulama Boyutu } \\
\hline \multirow{5}{*}{$\begin{array}{l}\text { 49. Programın etkin bir } \\
\text { şekilde uygulanabilmesi } \\
\text { için 5. sınıflarda sosyal } \\
\text { silgiler dersinin ders } \\
\text { saati arttırılmalıdır. }\end{array}$} & $\begin{array}{l}\text { Hiç } \\
\text { Katılmıyorum }\end{array}$ & 3 & 1,8 & \multirow{5}{*}{4,15} & \multirow{5}{*}{ Katıliyorum } \\
\hline & Katılmiyorum & 14 & 8,3 & & \\
\hline & $\begin{array}{l}\text { Kismen } \\
\text { Katıliyorum }\end{array}$ & 21 & 12,5 & & \\
\hline & Katıliyorum & 46 & 27,4 & & \\
\hline & $\begin{array}{l}\text { Tamamen } \\
\text { Katıliyorum }\end{array}$ & 84 & 50,0 & & \\
\hline \multirow{5}{*}{$\begin{array}{l}\text { 50. Sosyal bilgiler } \\
\text { dersinde ders kitabı ve } \\
\text { çalışma kitapları dışında } \\
\text { öğrencilerin } \\
\text { seviyelerine uygun } \\
\text { çeşitli kaynaklardan } \\
\text { yararlanılmalıdır }\end{array}$} & $\begin{array}{l}\text { Hiç } \\
\text { Katılmıyorum }\end{array}$ & 3 & 1,8 & \multirow{5}{*}{4,20} & \multirow{5}{*}{ Katıliyorum } \\
\hline & Katılmiyorum & 7 & 4,2 & & \\
\hline & $\begin{array}{l}\text { Kismen } \\
\text { Katıliyorum }\end{array}$ & 16 & 9,5 & & \\
\hline & Katıliyorum & 70 & 41,7 & & \\
\hline & $\begin{array}{l}\text { Tamamen } \\
\text { Katıliyorum }\end{array}$ & 72 & 42,9 & & \\
\hline \multirow{5}{*}{$\begin{array}{l}\text { 51. Sosyal bilgiler } \\
\text { dersine ayrilan ders } \\
\text { saati yeterlidir. }\end{array}$} & $\begin{array}{l}\text { Hiç } \\
\text { Katılmıyorum }\end{array}$ & 81 & 48,2 & \multirow{5}{*}{2,01} & \multirow{5}{*}{ Katılmiyorum } \\
\hline & Katılmiyorum & 41 & 24,4 & & \\
\hline & $\begin{array}{l}\text { Kismen } \\
\text { Katıliyorum }\end{array}$ & 16 & 9,5 & & \\
\hline & Katıliyorum & 23 & 13,7 & & \\
\hline & $\begin{array}{l}\text { Tamamen } \\
\text { Katıliyorum }\end{array}$ & 7 & 4,2 & & \\
\hline \multirow{5}{*}{$\begin{array}{l}\text { 52. Yöneticilerin ilgi } \\
\text { düzeyi programın } \\
\text { hedeflerinin } \\
\text { gerçekleştirilmesinde } \\
\text { önemli rol } \\
\text { oynamaktadır. }\end{array}$} & $\begin{array}{l}\text { Hiç } \\
\text { Katılmıyorum }\end{array}$ & 4 & 2,4 & \multirow{5}{*}{3,66} & \multirow{5}{*}{ Katıliyorum } \\
\hline & Katılmiyorum & 7 & 4,2 & & \\
\hline & $\begin{array}{l}\text { Kismen } \\
\text { Katıliyorum }\end{array}$ & 48 & 28,6 & & \\
\hline & Katıliyorum & 92 & 54,8 & & \\
\hline & $\begin{array}{l}\text { Tamamen } \\
\text { Katıliyorum }\end{array}$ & 17 & 10,1 & & \\
\hline
\end{tabular}

Not $=51$. maddesi ters yönde kodlanmaktadır. 
Tablo-6 incelendiğinde; öğretmenler programın etkin bir şekilde uygulanabilmesi için 5. sınıflarda sosyal bilgiler dersinin ders saati arttırılması gerektiği, sosyal bilgiler dersinde ders kitabı ve çalışma kitapları dışında öğrencilerin seviyelerine uygun çeşitli kaynaklardan yararlanılması ve yöneticilerin ilgi düzeyi programın hedeflerinin gerçekleştirilmesinde önemli rol oynaması konularında olumlu görüş belirtmişlerdir. Sosyal bilgiler dersine ayrılan ders saatinin yeterli olması konusunda da olumsuz görüş belirtmişlerdir.

\section{Tartışma ve Sonuç}

2017-2018 eğitim ögretim yılında ilk defa uygulanan 5. sınıf SBDÖP'ye yönelik oluşturulan alt problemlere ilişkin verilerin analizi sonucunda elde edilen bulgulardan hareketle aşağıdaki sonuçlara ulaşılmıştır. Ayrıca sonuçlar doğrultusunda bazı öneriler geliștirilmiştir.

Programın genel amaçları ve temel yaklaşımları boyutu ile ilgili elde edilen sonuçlara bakıldığında; öğretmenlerin çoğunluğu 5. sınıf SBDÖP'nin genel amaçlarının açık bir şekilde ifade edildiğini, Milli Eğitimin temel amaçları ile uyuştuğunu, programda benimsenen yaklaşımın bireyin toplumsal varoluşunu gerçekleştirmeye yönelik olduğunu, Sosyal Bilgiler ders kitabında yer alan kavramların rahatça anlaşılabilir şekilde açık-seçik ifade edildiğini, SBDÖP'de kazanımların öğrencilerin sınıf düzeyine uygun olduğunu, öğrencilerin ihtiyaçlarına uygun tasarlandığını, birbirini desteklediğini ve rahatça anlaşılabilir şekilde açık-seçik ifade edildiğini, sosyal bilgiler dersinde genel kazanımlar gerçekleştirilebildiğini ve kazanımlar belirlenirken öğretmen görüşlerine önem verildiğini, öğrencilerin sosyal bilgiler dersine olan ilgi düzeyleri programın hedeflerinin gerçekleştirilmesini etkilediğini düşünmektedir. Fakat öğretmenler SBDÖP'de kullanılan yaklaşımlar öğrencinin empati kurma yeteneğinin gelişmesine katkıda bulunmadığını kısmen düşünmektedir.

Programın genel amaçları ve temel yaklaşımları boyutu ile ilgili olarak alanyazın incelendiğinde;

Uslu (2007) tarafından gerçekleştirilen çalışmada öğretmenlerin çoğunluğu, SBDÖP'nın genel amaçlarının ve ders kitaplarda yer alan kavramların ve kazanımların rahatça anlaşılabilir şekilde açık-seçik ifade edildiğini, kazanımların sınıf düzeyine ve ögrenci ihtiyaçlarına uygun olduğunu, yeterli düzeyde gerçekleştirildiğini ve birbirini desteklediğini, kazanımlar belirlenirken öğrenci görüşlerine daha fazla ağırlık verildiğini ve öğrencilerin sosyal bilgiler dersine olan ilgi düzeylerinin programın hedeflerini gerçekleştirmesinde etkili olduğunu düşünmektedir. Bu sonuçlar araştırmadaki verileri destekler niteliktedir. Fakat bu araştırmada yaklaşımların öğrencilerin empati kurma becerileri üzerinde etkisi olduğu sonucuna da varılmıştır. $\mathrm{Bu}$ sonuç ise araştırmadaki verilerle farklılık göstermektedir. Ece (2007) tarafından gerçekleştirilen çalışmada 
katılımcıların çoğunluğu; SBDÖP kazanımlarının iyi belirlendiğini, kazanımların konularla bağlantılı olduğunu, kazanımların sınırlandırılıp sadeleştirildiğini ve öğrenci özelliklerine uygun olduğunu düşünmektedir. Kılıçoğlu (2007) tarafindan gerçekleştirilen çalışmada öğretmelerin büyük çoğunluğu; SBDÖP kazanımlarının öğrencilerin gelişim özelliklerine uygun olduğunu ve öğrencilerin ihtiyaçlarına uygun bir şekilde cevap verdiğini ve okullarımızda gerçekleştirilebilecek nitelikte olduğunu düşünmektedir. $\mathrm{Bu}$ sonuçlar araştırmanın verileri ile örtüşmektedir.

Programın vizyonu boyutu ile ilgili elde edilen sonuçlara bakıldığında; öğretmenlerin çoğunluğu SBDÖP'nin vizyonu açık bir şekilde ifade edildiğini, gerçekleştirmeye yönelik olduğunu ve çağımızın gerektirdiği insanın sahip olması gereken donanımı ifade ettiğini düşünmektedir.

Programın vizyon boyutu ile ilgili olarak alanyazın incelendiğinde; Uslu(2007) tarafindan gerçekleştirilen çalışmada öğretmenlerin büyük çoğunluğu SBDÖP'nin vizyonunun açık bir şekilde ifade edildiğini, içeriğin bu vizyonu gerçekleştirmeye yeterli olduğunu ve çağımızın gerektirdiği insanın sahip olması gereken donanımı ifade ettiğini düşünmektedir. $\mathrm{Bu}$ sonuçlar araştırmadaki verileri destekler niteliktedir.

Programın içerik boyutu ile ilgili elde edilen sonuçlara bakıldığında; öğretmenlerin çoğunluğu içeriğin genel amaçlara ulaşmayı sağlayacak nitelikte olduğunu, programı oluşturan temel öğeler genel amaçlar, kavram, değer ve beceri programda rahatça anlaşılabilir şekilde açık-seçik ifade edildiğini, SBDÖP, öğrencilerin kendine özgü becerileri kazanmasında ve kendi değer sistemlerini kurmada etkin bir rol oynadığını, öğrencileri araştırma ve incelemeye sevk ettiğini, diğer ders programları ile desteklendiğini, öğrencilerin gelecekteki yaşantılarına 1şık tutarak bireylerden beklenen niteliklerin gelişmesine yardımc1 olacağını ve bir bütün olarak amaçlandığı temel düşünceleri kazandıracağını, SBDÖP'de yer alan kavramlar öğrencilerin seviyesine uygun olduğunu, sosyal bilgiler ders kitabında kullanılan kavram haritaları sayesinde konu daha iyi anlaşıldığını, SBDÖP'nin içeriği geçmişte öğretilen konuları desteklediğini ve benimsenen temel yaklaşımın uygulanmasını gerçekleştirebildiğini, SBDÖP'yi alan öğrenciler çalışkan, araştırıcı, özverili, erdemli ve girişimci bir yapıya sahip olacağını, aile, okul ve toplum hayatının dayandığı temel ilkeleri ve toplum halinde yaşamanın zorunluluğunu ve sorumluluğunu kavrayacağını, ailelerine, vatanına, Atatürk ilke ve inkılaplarına bağlı insanlar olarak yetişeceğini, bugünkü uygarlığın uzun bir geçmişin eseri olduğunu kavrar, bu uygarlıkta Atatürk ve Türk milletinin hizmetini ve payını anlayarak 'milli kültürümüzü çağdaş uygarlık seviyesinin üzerine çıkarma' yolunda her fedakarlığı göze alma bilincini kazanacağını, Türk toplumunun birer üyesi olarak görev ve sorumluluk alabilecek hale geleceğini, aile bütünlüğüne bağlılık kazanacağını, ailenin refah ve mutluluğu için sorumluluk ve görev duygularını geliştireceğini ve gelecekte çalışmak istedikleri meslekler ile ilgili olarak temel bilgi ve becerileri kazanacağını, SBDÖP'de yer alan bilgiler 
öğrencilerin çevreleriyle olan uyumlarını kolaylaştıracağını ve çevre ilgili konuların programın genel amaçlarıyla örtüştüğünü düşünmektedir. Fakat Sosyal Bilgiler Programı'nın içeriği somuttan soyuta olacak şekilde düzenlenmediğini kısmen düşünmektedir.

Programın içerik boyutu ile ilgili olarak alanyazısı incelendiğinde; Uslu (2007) tarafından gerçekleştirilen çalışmada öğretmelerin büyük çoğunluğu; programı oluşturan beceri, kavram, değerler ve amaçların programda anlaşılır bir biçimde ifade edildiğini, programda yer alan kavramların öğrencinin seviyesine uygun olduğunu, programın öğrencilerin kendine özgü becerileri kazanmasında ve kendi değer sistemlerini kurmasında etkin bir rol oynadığını, öğrenciyi araştırma ve incelemeye sevk ettiğini, SBDÖP'yi alan öğrencilerin Türk toplumunun bir üyesi olarak görev ve sorumluluklarını alabilecek, ailesine, vatanına, Atatürk ilke ve inkılaplarına bağlı, çalışkan araştırıcı, özverili, erdemci, girişimci bir yapıya sahip, topluluk halinde yasamanın zorunluluğu ve sorumluluğunu bilen, milli kültürümüzü çağdaş uygarlık seviyesine çıkarma yolunda her fedakarlığı göze alabilecek, gelecekte seçeceği meslekle ilgili olarak temel bilgi ve becerileri kazanabilecek bir birey olarak yetiştiğini, bu program sayesinde kendilerinden beklenen niteliklerin geliştirilmesine yardımcı olarak geleceklerine 1 şı tutabileceğini, diğer ders programlarıyla desteklendiğini ve benimsenen temel yaklaşımın uygulanmasını gerçekleştirebildiğini, içeriğin geçmişte öğretilen konuları destekleyerek somuttan soyuta olacak şekilde düzenlendiğini ve genel amaçları sağlayacak nitelikte olduğunu ve ders kitaplarında yer alan kavram haritaları sayesinde konunun daha iyi anlaşıldığını düşünmektedir. Ece (2007) tarafından gerçekleştirilen çalışmada öğretmelerin çoğunluğu; SBDÖP'nın içeriğindeki konuların dengeli olarak dağıtıldığını, içerikte yer alan konuların önemli olduğunu ve içeriğin öğrencilerin ilgisini çektiğini, günlük hayatla ve diğer derslerle ilişkilendirildiğini ve "somuttan soyuta" ilkesine uygun olduğunu düşünmektedirler. Yazar (2008) tarafindan gerçekleştirilen çalışmada ise öğretmenler, SBDÖP 'nin içeriğinin öğrencilerin seviyelerine uygunluğuna, çağdaş ve güncel bilgilerden oluştuğuna ve içeriğin öğrencileri kazanımlara ulaştıracak nitelikte olduğuna katılmaktadırlar. Bu sonuçlar araştırmadaki verileri destekler niteliktedir.

Programın öğrenme öğretme boyutu ile alakalı ortaya çıkan sonuçlara bakıldığında; öğretmenlerinin çoğunluğu sosyal bilgiler dersinde kullanılması önerilen öğretim yöntem ve tekniklerinin öğrencilerin bilgi ve becerilerini yeniden yapılandırarak hayata geçirmelerine olanak sağladığını, sosyal bilgiler dersi programının uygulanmasında öğretmen yol gösterici, öğrencinin ise aktif durumda olduğunu, SBDÖP'de modern öğretim yöntem ve tekniklerine yeterince yer verildiğini, sosyal bilgiler dersinde öğrencilere yapıc1-yaratıcı faaliyetlere yöneltecek etkinlikler yapılabildiğini, SBDÖP'de yapılması tasarlanan etkinliklerin öğrencilerin gelişim özelliklerine uygun olduğunu, SBDÖP'nin yapılması gereken etkinliklerde öğrencilere ve öğretmenlere yol gösterebildiğini düşünmektedir. Fakat öğretmenler

http://dergipark.gov.tr/aicusbed 7/2 Ekim/October 2021 
SBDÖP'de öğrenme alanlarının işlenişi sırasında öğretmenlerin kullanacağı yeterli uygulama örnekleri bulunmadığını kısmen düşünmektedir.

Programın öğrenme öğretme boyutu ile ilgili olarak alanyazısı incelendiğinde; Uslu (2007) tarafından gerçekleştirilen çalışmada öğretmelerin çoğunluğu; sosyal bilgiler dersinde kullanılması önerilen öğretme yöntem ve tekniklerinin öğrencilerin bilgi ve becerilerini yeniden yapılandırarak hayata geçirmelerine olanak sağladığı, programın uygulanmasında öğretmenin yol gösterici öğrencinin aktif durumda olduğu, programda modern öğretim yöntem ve tekniklerine yeterince yer verilmediği, ünitelerin islenmesinde öğretmenlere yeterli uygulama örneklerinin sunulduğu, derste öğrencileri yapıcı yaratıcı faaliyetlere yöneltici etkinlikler yapılabildiği bu etkinliklerin öğrencilerin gelişim özelliklerine uygun olduğu ve programın yapılması gereken etkinliklerde ögrenci ve öğretmenlere yol gösterebilecek nitelikte olduğu görüşlerine katıldıkları sonucuna ulaşı1mıştır. $\mathrm{Bu}$ sonuçlar araştırmanın verileri ile örtüşmektedir.

Programın ölçme ve değerlendirme boyutu ile ilgili elde edilen sonuçlara bakıldığında; öğretmenlerin çoğunluğu SBDÖP'nin öğretmenlerin ölçme araçları geliştirmesi açısından yol gösterici olduğunu, SBDÖP'de değerlendirme işleminin yapılabilmesi için gerekli ölçütlere yer verildiğini ve öğrencilerin yapmış oldukları etkinliklerin değerlendirilebilmesi amacıyla öğretmenlere rehberlik yapacak açıklamalara yer verildiğini düşünmektedir.

Programın ölçme ve değerlendirme ile ilgili olarak alanyazısı incelendiğinde; Ece (2007), tarafından gerçekleştirilen çalışmada öğretmenlerin çoğunluğu; programın değerlendirme konusunda öğretmene yol gösterici olduğu düşünmektedir. Uslu (2007), tarafindan gerçekleştirilen çalışmada SBDÖP'nin öğretmenlerin ölçme araçları geliştirmesi açısından yol gösterici olduğu, değerlendirme işleminin yapılabilmesi açısından gerekli ölçütlere yer verildiği, öğrencilerin yaptıkları etkinliklerin değerlendirilebilmesi amacıyla öğretmenlere rehberlik yapacak açıklamalara yer verildiği görüşlerine katıldığı sonucuna ulaşılmıştır. Sağlam (2014) tarafindan gerçekleştirilen çalışmada program, ölçme ve değerlendirme etkinliklerinde öğretmene yeterince yardımcı olmaktadır ifadesi orta düzeyde olumlu bulunmuştur. Bu sonuçlar araştırmadaki verileri desteklemektedir.

Programın uygulama boyutu ile ilgili elde edilen sonuçlara bakıldığında; öğretmenlerin büyük çoğunluğu programın etkin bir şekilde uygulanabilmesi için 5.sınıflarda sosyal bilgiler dersinin ders saatinin arttırılması ve sosyal bilgiler dersinde ders kitabı dışında öğrencilerin seviyelerine uygun çeşitli kaynaklardan yararlanılması gerektiğini ve yöneticilerin ilgi düzeyi programın hedeflerinin gerçekleştirilmesinde önemli rol oynadığını düşünmektedir.

Programın uygulama ile ilgili olarak alanyazısı incelendiğinde; Uslu (2007), yaptığı çalışmada sosyal bilgiler dersinin ders saatlerinin artırılması gerektiği ve yöneticilerin ilgi düzeyinin hedefleri gerçekleştirmede önemli rol

http://dergipark.gov.tr/aicusbed 7/2 Ekim / October 2021 
oynadığı görüsüne katıldıkları sonucuna ulaşılmıştır. $\mathrm{Bu}$ sonuçlar araştırmanın verileri ile örtüşmektedir.

"Sosyal bilgiler öğretmenlerinin; meslekteki kıdem değişkenine göre 5. Sınıf SBDÖP'nin genel amaçları ve temel yaklaşımı, vizyonu boyutuna yönelik görüşleri farklılaşmakta mıdır?' alt problemine karşılık olarak araştırmada aşağıdaki sonuçlara ulaşılmıştır:

Öğretmenlerin mesleki kıdemlerine göre; programın genel amaçları ve temel yaklaşımı, vizyonu boyutuna verdikleri yanıtlar arasında anlamlı bir fark olmadığg gözlemlenmiştir.

Mesleki kıdem değişkeni ile ilgili olarak alanyazısı incelendiğinde; Ece (2007), Sağlam (2014) ve Kösterelioğlu ve Özen (2014) yaptığ çalışmada fark bulunmamıştır. Kamber, Acun ve Akar (2011), mesleki kıdem değişkenine göre kazanım ve değerlendirme arasında anlamlı bir fark bulunmamıştır. Bu sonuçlar araştırmadaki verileri desteklemektedir.

Elde edilen bulgular çerçevesinde yapılabilecek öneriler ise şöyle ifade edilebilir:

1- $\quad$ SBDÖP'de kullanılan yaklaşımlar, öğrencinin empati kurma yeteneğinin gelişmesine katkı sağlayacak hale getirilmelidir.

2- SBDÖP'de öğrenme alanlarının işlenişi sırasında öğretmenlerin kullanabileceği yeterli uygulama örnekleri bulunmalıdır.

3- $\quad$ Sosyal bilgiler dersinde ders kitabı dışında öğrenci seviyesine uygun çeşitli kaynaklardan faydalanılmalıdır.

4- SBDÖP'nin amaçlarının gerçekleşmesi için öğretmenler, somuttan soyuta ilkesine uygun materyaller kullanarak öğrencilerin öğrenmeye istekli olmalarını ve etkinliklere doğrudan katılmalarını sağlamalıdır.

5- Programın hedeflerinin gerçekleşmesinde yöneticiler aktif rol almalidır.

6- Kazanımların kavratılabilmesi ve öğrenilenlerin pekiştirilebilmesi için ders saati arttırılmalıdır.

\section{Kaynakça}

Akmeşe, S. (2019). 2017 Ortaokul 5. Sinıf Sosyal Bilgiler Öğretim Programının Öğretmen Görüşlerine Göre Değerlendirilmesi (Yüksek Lisans Tezi), Marmara Üniversitesi

Çalışkan, Ö. (2019). 2017-2018 Yeni Sosyal Bilgiler Öğretim Programında Yer Alan 5. Sinıf Sosyal Bilgiler Dersi Kazanımlarının Ögretmen Görüşlerine Göre Gerçekleştirilme Düzeyinin Belirlenmesi ( Yüksek Lisans Tezi) ,Tokat Gaziosman Paşa Üniversitesi

Çalışkan, U. (2014). Ortaokul 5. Sinıf Sosyal Bilgiler Öğretim Programının Öğretmen Görüşlerine Göre Değerlendirilmesi- Bolu ili Örnĕgi ( Yüksek Lisans Tezi) , Abant İzzet Baysal Üniversitesi 
Coşkun, A. (2007). İlköğretim 4.ve 5. sinıfları Sosyal Bilgiler Programı Hakkında Öğretmen Görüşlerine İlişkin Nitel Bir Çalışma (Yüksek Lisans Tezi), Başkent Üniversitesi

Ece, B. (2007). İlköğretim Birinci Kademe 2005 Sosyal Bilgiler Programının Ögretmen Görüşlerine Gore Değerlendirilmesi-Afyonkarahisar ili Örneği(Yüksek Lisans Tezi), Afyonkarahisar Üniversitesi

Firat, M. N. (2019). Yenilenen 5. Sinıf Sosyal Bilgiler Dersi Programına İlişkin Öğretmen Görüşleri (Yüksek Lisans Tezi), Amasya Üniversitesi

Kalayc1, E. (2007). İlköğretim 4. Ve 5. Sinıf Sosyal Bilgiler Programının Ögrretmen Görüşlerine Göre Değerlendirilmesi ( Yüksek Lisans Tezi), Atatürk Üniversitesi

Kamber T. , Acun İ. , Akar C. (2011). İlköğretim Birinci Kademe Sosyal Bilgiler Öğretim Programının Uygulanabilirliği. Uşak Üniversitesi Sosyal Bilimler Dergisi, 4/2, 195-218

Karasar, N. (2005). Bilimsel araştırma yöntemi (15. Basım). Nobel Yayın Dağıtım

Kan, Ç. (2010). A.B.D ve Türkiye'de Sosyal Bilgilerin Tarihsel Gelişimi. Gazi Eğitim Fakültesi Dergisi, 30/2, 663-672

Kılıçoğlu, G. (2007). İlkögretim 4. Ve 5. Sinıf Sosyal Bilgiler Programına İlişkin Öğretmen Görüşlerinin Değerlendirilmesi (Kars İli Örneği)( Yüksek Lisans Tezi), Kafkas Üniversitesi

Kösterelioğlu, İ. ve Özen, R. (2014). Dördüncü ve Besinci Sınıf Sosyal Bilgiler Dersi Öğretim Programının Öğelerinin Değerlendirilmesi (Bolu İli Örneği). Amasya Üniversitesi Ĕ̆itim Fakültesi Dergisi, 3(2), 286-316

MEB (1998), Tebliğler Dergisi, 533 (2487)

MEB (2015), Sosyal Bilgiler Dersi 4, 5, 6 ve 7. Sınıflar Öğretim Programı, MEB Yayınları

Memişoğlu, H. (2012). İlköğretim 4-5 Sosyal Bilgiler Ders Programının Öğretmen Görüşlerine Göre Değerlendirilmesi. Eğitim Öğretim Araştırmaları Dergisi, Cilt:1-2, 66-81

Öztürk, C.(2009). Sosyal Bilgiler: Toplumsal Yaşama Disiplinler arası Bir Bakış. C. Öztürk (ed), Sosyal Bilgiler Öğretimi, 1/28. PegemA Yayınları

RG. (1997), T.C. Resmi Gazete, 18 Ağustos, (23084)

Sağlam, E. (2014). 5. Sınıf Sosyal Bilgiler Dersi Öğretim Programı İle İlgili Öğretmen Görüşlerinin Değerlendirilmesi, Erzincan Üniversitesi

http://dergipark.gov.tr/aicusbed 7/2 Ekim / October 2021 
Semenderoğlu, A. ve Gülersoy A. E. (2005). Eski ve Yeni 4-5. Sinıf Sosyal Bilgiler Öğretim Programlarının Değerlendirilmesi, Dokuz Eylül Üniversitesi

TTKB (2017), Müfredatta Yenileme ve Değişiklik Çalışmalarımız Üzerine... 18 Temmuz 2017 Basinı Toplantisl Metni (https://ttkb.meb.gov.tr/meb iys dosyalar/2017 07/18160003 basin aciklamasi-program.pdf )

Uslu, E. (2007). İlköğretim 4. ve 5. Sinıf Sosyal Bilgiler Programının Öğretmen ve İdareci Görüşleri Çerçevesinde Değerlendirilmesi(Yüksek Lisans Tezi), Niğde Üniversitesi

Yazar, O. (2008). İlkögretim 4. ve 5. Sinıf Sosyal Bilgiler Dersi Öğretim Programlarına İlişkin Ögretmen Görüşlerinin İncelenmesi(Yüksek Lisans Tezi), Atatürk Üniversitesi

\section{Extended Summary}

\section{Evaluation of The Updated 5th. Grade Social Studies Curriculum According to Teacher's Opinions}

In today's world called the information age, there are rapid changes and developments especially in the fields of science and technology. We need to keep up with these changes and developments in these fields as a country globally.

The aim of the study was to evaluate the 5th-Grade Social Studies Curriculum updated according to the opinions of the teachers. In response to the subproblem of "What are the opinions of social studies teachers regarding the General Objectives and Basic Approach, Vision, Content, Learning-Teaching Process, Measurement and Evaluation, Application Aspects of the 5th Grade Social Studies Curriculum?", the following results were obtained in the research:

The sample group of the study consists of 168 social studies teachers working in metropolitan districts of Erzurum province (Aziziye, Palandoken, Yakutiye) in the 2017-2018 academic year. In the research, the data were collected with a personal information form developed by USLU (2007) containing information about the participants and a questionnaire form, which consists of six sections and is a screening method that includes the opinions of the participants regarding the updated 5th-Grade SSC. SPSS 22.00 statistical package program was used for the analysis of the data. The differences between the answers given to the questionnaire according to the professional seniority of the teachers included in the research were examined by Kruskal Wallis $\mathrm{H}$ test. According to the answers given by the teachers to the questionnaire, it was aimed to learn the general objectives, vision, content, learning and teaching processes, measurement and evaluation and application aspects of 5thgrade SSC and the expectations of the teachers in general. This research, which aims to evaluate the updated 5th-Grade Social Studies Curriculum according to the opinions of the teachers, is a screening model. The screening model was based on reflecting an existing stance in its own conditions and as it is (Karasar, 2005). In this context, it was aimed to describe the opinions and suggestions of social studies

http://dergipark.gov.tr/aicusbed 7/2 Ekim /October 2021 
teachers who attend the 5th-grade social studies course of secondary schools in line with the current situation. The sample of the study consists of two hundred (200) social studies teachers working in Erzurum metropolitan districts (Aziziye, Palandoken, Yakutiye). All teachers were reached, but since the study was voluntary, the feedback was received from one hundred sixty-eight (168) of them. Accordingly, the rate of return for the study data is $84 \%$ for the questionnaire.

It was also examined relationally whether the Fifth-Grade Social Studies Curriculum varied according to the acquisition, content, educational status, evaluation and meeting expectations, professional seniority, educational background, participation in in-service training and examination of the program.

Teachers expressed a positive opinion about the subjects that the teaching methods and techniques recommended to be used in the social studies course allows students to realize their knowledge and skills by restructuring them, that the teacher is guiding in the implementation of the Social Studies Curriculum and the student is active, that the modern teaching methods and techniques are sufficiently included in the Social Studies Curriculum. Activities to direct students to constructive and creative ways are carried out in the Social Studies course, that the activities planned to be carried out in the Social Studies Curriculum are in accordance with the developmental characteristics of the students. They expressed a negative opinion about the lack of sufficient practical examples to be used by teachers during the teaching of units in the Social Studies program. According to the answers given to sub-problem of "Do the opinions of the social studies teachers on the General Objectives and Basic Approach, Vision, Content, Learning-Teaching Process, Measurement, and Evaluation and Application aspects of the 5th-Grade Social Studies Curriculum differ according to "Professional Seniority" variable?", all KW values of the questionnaire regarding the "Content of the Program", "General Objectives and Basic Approach of the Program", "Vision of the Program", "Learning-Teaching Process", "Measurement and Evaluation" and "Application Aspect" were found to be insignificant at $p>0.05$ significance level according to the professional seniority of the teachers. This finding shows that there is no difference between answers of the teachers to the "Content of the Program", "General Objectives and Basic Approach of the Program", "Vision of the Program", "Learning-Teaching Process", "Measurement and Evaluation" and "Application Aspect" of the questionnaire according to their professional seniority. They expressed a positive opinion about the subjects that the general objectives of the Social Studies Program are clearly expressed, that the general objectives of the Social Studies Program are compatible with the basic objectives of national education, that the approach adopted in the Social Studies Program is aimed at realizing the social existence of the individual, that the concepts in the social studies textbook are clearly expressed in an easily understandable way, that the acquisitions in the Social Studies Program are suitable for the class level of the students, that the acquisitions in the Social Studies Program are designed in accordance with the needs of the students, that the acquisitions in the Social Studies Program support each other, that the acquisitions in the Social Studies Program are clearly expressed, that the acquisitions in the Social Studies course can be realized, that the opinions of the teachers are given more importance when determining the acquisitions in the social studies course, and that the students' interest levels in the social studies course affect the realization of the objectives of the

http://dergipark.gov.tr/aicusbed 7/2 Ekim / October 2021 
program. They expressed a negative opinion about the subject that the approaches used in the Social Studies Program contribute to the development of the student's ability to empathize.

They expressed a positive opinion about the subjects that the content is sufficient to achieve general purposes, that the skills, concepts, values and general objectives which are the basic elements that make up the Social Studies Program are expressed clearly in the program in an easily understandable way.

Teachers expressed a positive opinion about the subjects that the Social Studies Program is a guide for teachers to develop measurement tools, that Social Studies Program includes the necessary criteria for the evaluation process and the explanations that will guide the teachers in order to evaluate the activities of the students. They expressed a positive opinion about the subjects that the Social Studies course hours should be increased in 5th-grades in order for the program to be implemented effectively, that various resources should be used in the social studies course other than the textbooks and workbooks suitable for the levels of the students, that the guidebooks can guide the teachers and that the level of interest of the administrators plays an important role in the realization of the objectives of the program. They also expressed a negative opinion about the adequacy of the course hours allocated to the social studies course.

The results of the sub-problems created by MoNE for the 5th-grade social studies curriculum implemented for the first time in the 2017-2018 academic year are as follows.

According to the opinions of the teachers participating in the research, when the results obtained regarding the general objectives and basic approaches aspects of the program are examined; the majority of social studies teachers think that the general objectives of 5th grade SSC are clearly expressed, that they are in accordance with the basic objectives of National Education, that the approach adopted in the program is aimed at realizing the social existence of the individual, that the concepts in the Social Studies textbook are clearly expressed, that the acquisitions in SSC are suitable for the class level of the students, that the acquisitions are designed in accordance with the needs of the students, that the acquisitions support each other and are expressed clearly, that the general acquisitions can be achieved in the social studies course, and that the interest levels of the students in the social studies course affect the achievement of the objectives of the program. In addition, teachers partly think that the opinions of the teachers are given importance when determining the acquisitions in the social studies course. However, teachers partly think that the approaches used in SSC do not contribute to the development of the student's ability to empathize.

There should be sufficient practical examples to be used by teachers during the teaching of learning areas in the Social Studies Program. Various resources suitable for the student level should be used in the social studies course other than the textbook. In order for the objectives of the Social Studies Curriculum to be realized, activities that will enable students to be willing to learn, show interest in the course, participate directly in the activities and transform the knowledge and skills they have learned into behaviors in the social environment should be included. In order for the objectives of the Social Studies Curriculum to be realized, families should support in

http://dergipark.gov.tr/aicusbed 7/2 Ekim/October 2021 
Güncellenen 5. Sınıf Sosyal Bilgiler Öğretim Programının Öğretmen Görüşlerine Göre

Değerlendirilmesi $\mid \mathbf{5 7}$

achieving the goals and cooperate with the teacher. Differences between regions should be taken into account in the program. The number of measurement and evaluation activities at the end of the units of the textbooks should be increased. In order for the acquisitions to be applied to all students in the classrooms, it is necessary to reduce the class sizes. Course hours should be increased in order to reinforce the learned subjects and to comprehend the acquisitions. 